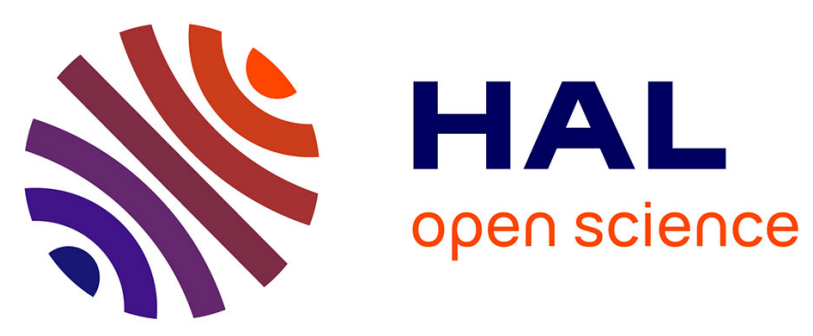

\title{
Interest of novel N-alkylpyridinium-indolizine hybrids in the field of Alzheimer's disease: Synthesis, characterization and evaluation of antioxidant activity, cholinesterase inhibition, and amyloid fibrillation interference
}

Isabelle Baussanne, Olga Firstova, Andreea Botezatu Dediu, Camille Larosa, Bianca Furdui, Ioana Ottilia Ghinea, Aline Thomas, Sabine Chierici, Rodica Dinica, Martine Demeunynck

\section{To cite this version:}

Isabelle Baussanne, Olga Firstova, Andreea Botezatu Dediu, Camille Larosa, Bianca Furdui, et al.. Interest of novel N-alkylpyridinium-indolizine hybrids in the field of Alzheimer's disease: Synthesis, characterization and evaluation of antioxidant activity, cholinesterase inhibition, and amyloid fibrillation interference. Bioorganic Chemistry, 2021, 116, pp.105390. 10.1016/j.bioorg.2021.105390 . hal-03430921

\section{HAL Id: hal-03430921 \\ https://hal.science/hal-03430921}

Submitted on 19 Nov 2021

HAL is a multi-disciplinary open access archive for the deposit and dissemination of scientific research documents, whether they are published or not. The documents may come from teaching and research institutions in France or abroad, or from public or private research centers.
L'archive ouverte pluridisciplinaire HAL, est destinée au dépôt et à la diffusion de documents scientifiques de niveau recherche, publiés ou non, émanant des établissements d'enseignement et de recherche français ou étrangers, des laboratoires publics ou privés. 


\title{
Interest of novel N-alkylpyridinium-indolizine hybrids in the field of Alzheimer's disease: synthesis, characterization and evaluation of antioxidant activity, cholinesterase inhibition, and amyloid fibrillation interference
}

Isabelle Baussanne ${ }^{a}$ Olga Firstova, ${ }^{a, b}$ Andreea Botezatu Dediu, ${ }^{c}$ Camille Larosa ${ }^{\mathrm{b}}$ Bianca Furdui, ${ }^{\mathrm{c}}$ Ioana Ottilia Ghinea ${ }^{\mathrm{c}}$ Aline Thomas, ${ }^{\mathrm{a}}$ Sabine Chierici, ${ }^{* b}$ Rodica Dinica, ${ }^{* \mathrm{c}}$ Martine Demeunynck $^{\mathrm{a}}$

${ }^{a}$ Univ. Grenoble Alpes, CNRS, DPM, Grenoble, France

${ }^{b}$ Univ. Grenoble Alpes, CNRS, DCM, Grenoble, France: e-mail: sabine.chierici@univgrenoble-alpes.fr

${ }^{c}$ Dunarea de Jos University of Galaţi, Faculty of Science and Environment, 111 Domneasca Street, 800201, Galaţi, phone: 0336130 251, fax: 0336130 285, e-mail: rodinica@,ugal.ro

\begin{abstract}
A small library of molecules combining indolizine and $\mathrm{N}$-alkyl pyridinium was synthesized and evaluated in a multi-target-directed-ligand strategy for Alzheimer's disease (AD) treatment. The new compounds were classified in three series depending on the number of methylene residues linking the two heterocycles (Ind-PyCx with $\mathrm{x}=0,2$ or 3 ). The molecules were synthesized from the corresponding bis-pyridines by two-step formation of the indolizine core including mono-alkylation of pyridine and 1,3-dipolar cycloaddition with an alkylpropiolate. Their activities against AD's key-targets were evaluated in vitro: acetyl- and butyrylcholinesterase (AChE and $\mathrm{BChE}$ ) inhibition, antioxidant properties and inhibition of amyloid fibril formation (ThT assays). None of the three series showed significant activities against all the targets. The Ind-PyC2 and Ind-PyC3 series are relatively active on eeAChE and hAChE ( $\mu \mathrm{M}$ IC50 values). Except compound $\mathbf{1 0}$ and 15, charged molecules appeared also active against eqBChE with micromolar $\mathrm{IC}_{50}$, while they lost their activity on $\mathrm{hBChE}$. Comparative molecular modeling of 13 and 15 docked in hAChE and hBChE highlighted the importance of the substituent $\mathrm{p}$ methoxybenzoyl or methyloxycarbonyl located on the indolizine part for the binding. The molecules displayed antioxidant activity at the highest tested concentration, up to 95\% inhibition of DPPH radical scavenging for 10. Most of the Ind-PyC2 and Ind-PyC3 hybrids were able also to interact with amyloid fibers even if the observed inhibitory effect on fibrillation process was observed at a high $100 \mu \mathrm{M}$ concentration. For the Ind-PyC0 series, despite the fact that their spectroscopic properties did not allow their evaluation with ThT assay, they showed interesting features in the presence of preformed fibers. In particular, the sharp increase of the fluorescence of $\mathbf{3}$ in the presence of amyloid fibers is a promising indication of the potential use of this series as fluorescent amyloid fibrillation reporter.
\end{abstract}

\section{Introduction}

The Alzheimer disease (AD) is a multifactorial neurodegenerative pathology characterized by oxidative stress and inflammatory processes, deposition of senile plaques and neurofibrillary tangles, not to forget the choline deficit due to neuron degeneration ${ }^{1}$. Up to now, acetylcholinesterase (AChE) inhibitors are the only molecules that have entered the clinic ${ }^{2}$, however these drugs only delay the AD progression by increasing the local acetylcholine level. In recent years the interest for these drugs has been questioned due to the existence of side- 
effects and lack of proven long-term efficiency, however cholinesterase (ChE) inhibitors targeting AChE and/or BChE (butyrylcholinesterase) remain the paradigm in the search of new drugs $^{3}$. In an effort to improve the effectiveness of these treatments and considering the complexity of $\mathrm{AD}$, the multi-target-directed ligands (MTDL) approach has gained a growing importance ${ }^{4-8}$. In this approach, two or three AD-related features are simultaneously targeted by designing molecules that will conjugate $\mathrm{ChE}$ inhibition with other properties, such as antioxidant activities, or $\beta$-amyloid anti-aggregation effects. In a commonly used approach, heterodimers are prepared by linking a known AChE inhibitor to a molecule aimed to a different activity or biological target ${ }^{9,10}$. A wide variety of such hybrids have been prepared as recently reviewed ${ }^{11}$. In recent years, pyridinium containing hybrids have been reported in the literature ${ }^{12-}$ ${ }^{16}$. Most of these cationic hybrids simultaneously target $\mathrm{AChE}$ and/or BChE, $\beta$-amyloid aggregation and oxidative stress.

Our groups have been involved for several years in the synthesis and study of the physical, chemical and biological properties of heterocyclic compounds made of pyridinium salts and indolizines. Both heterocycles possess a wide variety of interesting properties that have been reviewed recently ${ }^{17-19}$ (for examples of active molecules, see Figure 1). It is worth highlighting the fluorescence properties of the indolizine nucleus which has been used in the design of fluorescent tags or markers ${ }^{20-22}$.

Interestingly in the field of $\mathrm{AD}$, several pyridinium salts have been designed to interfere with ChE activity as mentioned above $\mathrm{e}^{9,10,14,15}$ and it is worth citing methoxime and obidoxime that are potent agents against nerve toxin action ${ }^{23}$. Both pyridiniums and indolizines compounds have also shown significant antioxidant properties ${ }^{24,25}$. Starting from these considerations it was tempting to evaluate the indolizines and pyridinium derivatives that we are developing in our groups as MTDL's against AD. Three series of derivatives were envisioned as possible candidates, symmetrical bis-pyridinium salts or bis-indolizines, and N-alkylpyridiniumindolizine hybrids. If bis-pyridinium salts are already known structures in this field ${ }^{15,26-28}$, the low solubility of the bis-indolizines in water constitutes a severe limitation to their study. Nevertheless, preliminary investigations to this work confirmed the potential as antioxidant and acetylcholinesterase inhibitors of both symmetrical bis-pyridiniums and bis-indolizines (unpublished data, see SI). To make the most of each heterocycle's properties, we decided to focus on hybrid molecules containing both an indolizine ring and a pyridinium moiety bearing various $\mathrm{N}$-substituents.
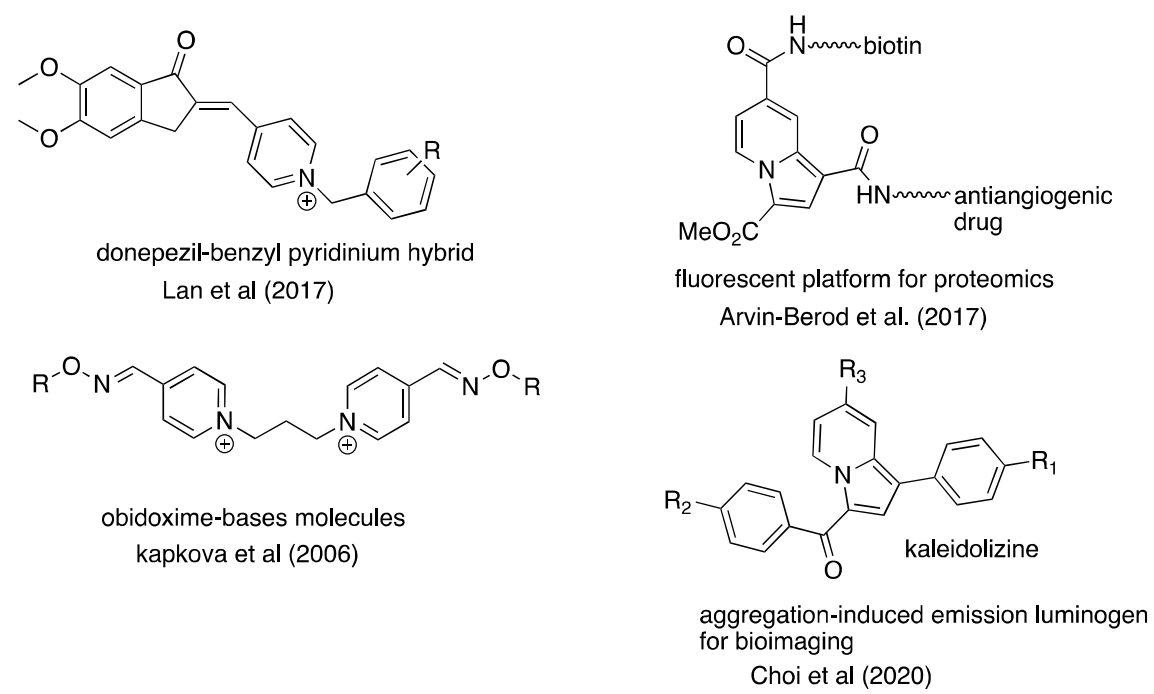

Figure 1. Examples of pyridinium salts and indolizine derivatives of biological interest. 
A first series of N-alkylpyridinium-indolizines (Figure 2A, Ind-PyC0 series, compounds 1-4) was synthesized previously to this work ${ }^{29,30}$. We describe here the synthesis of two other series that differ by the length of the aliphatic linker (from 0 to 2 or 3 methylenes), and by the nature of the substituents carried by both heterocycles (Figure 2A). This small library was evaluated against several current $\mathrm{AD}$ 's target strategies, i.e. $\mathrm{AChE}$ and $\mathrm{BChE}$ inhibition, antioxidant activity, and amyloid fibril formation inhibition. The results were compared to those of the corresponding bis-pyridinium salts (Figure 2B). Ellman and DPPH assays were used to assess the ChE inhibition and antioxidant ability of the compounds, respectively. In an effort to understand the factors involved in cholinesterase inhibition, docking calculations were performed with the most relevant hybrid molecules, and the influence of the structures on the binding modes will be discussed. Finally, the interference of the molecules on amyloid fibrillation was investigated using short peptide models from tau protein ${ }^{31-34}$.

A) Indolizine-pyridinium hybrids<smiles>[R7]C(=O)c1cc(C(=O)OCC)c2cc(-c3ccncc3)ccn12</smiles><smiles>[R]C(=O)c1cc(C(=O)OCC)c2cc(-c3cc[n+]([Y])cc3)ccn12</smiles>

Ind-PyC0 series
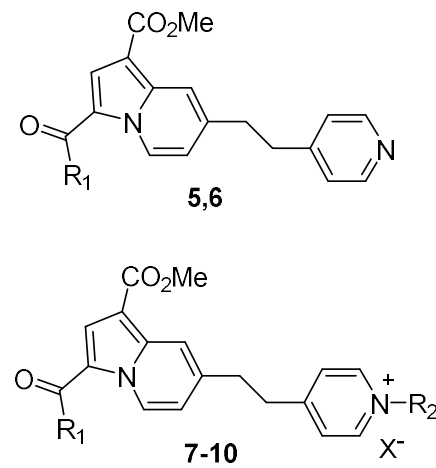

Ind-PyC2 series<smiles>[Y16]CCc1ccn2c(C([R])=O)cc(C(C)=O)c2c1</smiles>

11,12<smiles>[Y]C(=O)c1cc(C([R1])=O)n2ccc(CCCc3cc[n+]([R2])cc3)cc12</smiles>

Ind-PyC3 series

$$
\mathrm{X}^{-}=\mathrm{Br}^{-}, \mathrm{I}^{-} \quad \mathrm{R}_{1}=\mathrm{OMe}, \mathrm{p}-\mathrm{Ph}-\mathrm{R}
$$<smiles>[R]=CCCCO</smiles>

B) Bis-pyridinium salts

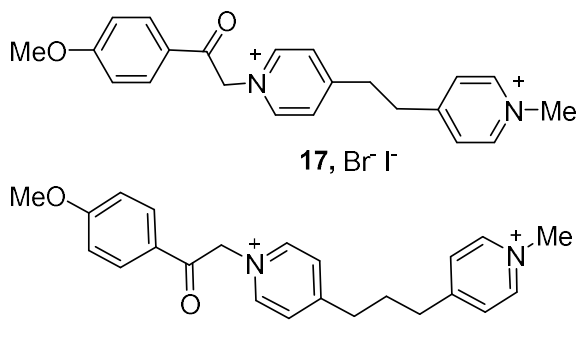

19, $\mathrm{Br}^{-}$

BisPy series
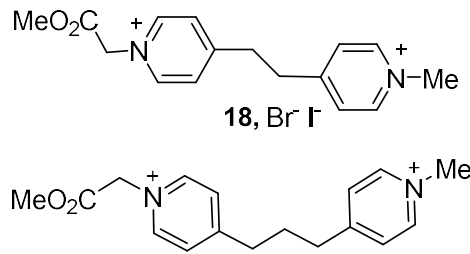

20, $\mathrm{Br}^{-} \mathrm{I}^{-}$

Figure 2. Hybrid molecules studied in the present work.

\section{Results and discussion}

\section{ADMET molecular descriptors}

First of all, considering the size and the positive charge carried by our molecules, it appeared important to check ADMET descriptors of the hybrids. As a matter of fact, for a long time uncharged small lipophilic molecules were the only candidates for central nervous system 
(CNS) targeting, however the discovery of specific Organic Cation Transporters (OCT), enabling charged molecules to pass through the blood brain barrier (BBB) to enter into the brain, changed this paradigm ${ }^{35,36}$. Actually, most CNS active drugs bear basic amines and are therefore positively charged at $\mathrm{pH}=7.4^{37}$.

To help the efficient designing of new molecules as CNS candidates, ADMET rules were adapted and a series of key parameters were selected ${ }^{37}: 1$. Lipophilicity with the calculated partition coefficient $\log \mathrm{P}$, ideally found between 0.4 and 5.1;2. Distribution at $\mathrm{pH}=7.4$ with LogD ranging between 0.4 and 3.8; 3. Molecular weight, average $=305 ; 4$. Number of $\mathrm{H}$-bond donors $\leq 2$; and 5 . Polarity with polar surface area (PSA) ranging between 16 and $86 \AA^{2}$. This last criterium has been pointed out by other authors as the most important factor, with PSA $<90^{38}$, along with MW $<450$ and $\operatorname{LogD}$ ranging between 0 and 3 .

We calculated a set of ADMET descriptors. The data are collected in Table 1. For comparison, we also calculated the data for the symmetrical bis-pyridinium salts and bis-indolizines which were studied in a previous unpublished work (1'a-c/2'a-c and $\mathbf{3}$ 'a-c/4'a-c respectively, see Table S5). It is worth noting the discrepancy that may be found using different calculation softwares, however our purpose was mainly the comparison of closely related structures. All calculations were made using Marvin software.

The pyridine-indolizines $(\mathbf{1}, \mathbf{5}, \mathbf{6}, \mathbf{1 1}$ and $\mathbf{1 2})$ are not or only partly protonated at $\mathrm{pH} 7.4$ (calculated $\mathrm{pKa}$ at 4.6 for $\mathbf{1}$ and 5.6 for the other compounds), leading to a large increase in lipophilicity reflected by higher LogP values. Alkylation of the pyridine ring gives monocationic molecules in a large $\mathrm{pH}$ range, thus conferring to the molecules ADMET values compatible with CNS potential drugs ${ }^{39}$.

In the Ind-PyC0 series, the major difference is found with $\mathbf{3}$, in which the presence of a nitro group significantly increases the PSA value to $94.8 \AA^{2}$, i.e. the highest value in this hybrid library, compared to $60.9 \AA^{2}$ for the methoxy substituted analog 4.

In the Ind-PyC2 series (compounds 7-9), the nature of the N-pyridine group (methyl, 3,5dimethoxybenzyl, 3-hydroxypropyl) influences the PSA values in some extent (from 60.9 to 81.1). Replacing methyl by the bulky 3,5-dimethoxybenzyl group increases LogP value, the more hydrophilic 3-hydroxypropyl group having the opposite effect.

In the $\mathrm{C} 2$ and $\mathrm{C} 3$ series, exchanging the more hydrophobic p-methoxybenzoyl group on indolizine ring by the methyloxycarbonyl group has no effect on PSA, but notably decreases $\operatorname{LogP}$ values (from 0.65 for $\mathbf{1 3}$ to -0.64 for $\mathbf{1 5}$, or from 2.06 for $\mathbf{1 4}$ to 0.77 for $\mathbf{1 6}$ ). Increasing the length of the linker, from 0 to 3 methylenes, has no effect on PSA, but leads to an increase in lipophilicity ( $\operatorname{LogP}$ ranging from -0.32 for 4 to 0.65 for 13 ).

\begin{tabular}{|c|c|c|c|c|}
\hline Compounds & $\begin{array}{l}\text { H bond } \\
\text { acceptor } \\
\text { sites }^{\mathrm{a}}\end{array}$ & M+ & $\begin{array}{l}\log P \\
(\log D)^{b}\end{array}$ & $\begin{array}{l}\text { Polar } \\
\text { Area }^{\mathbf{c}} \\
\text { PSA } \AA^{2}\end{array}$ \\
\hline \multicolumn{5}{|c|}{ Ind-PyC0 series } \\
\hline & 5 & 370.4 & $\begin{array}{l}3.78 \\
(3.77)\end{array}$ & 60.6 \\
\hline $\mathrm{CO}_{2} \mathrm{Et}$ & & & & \\
\hline
\end{tabular}




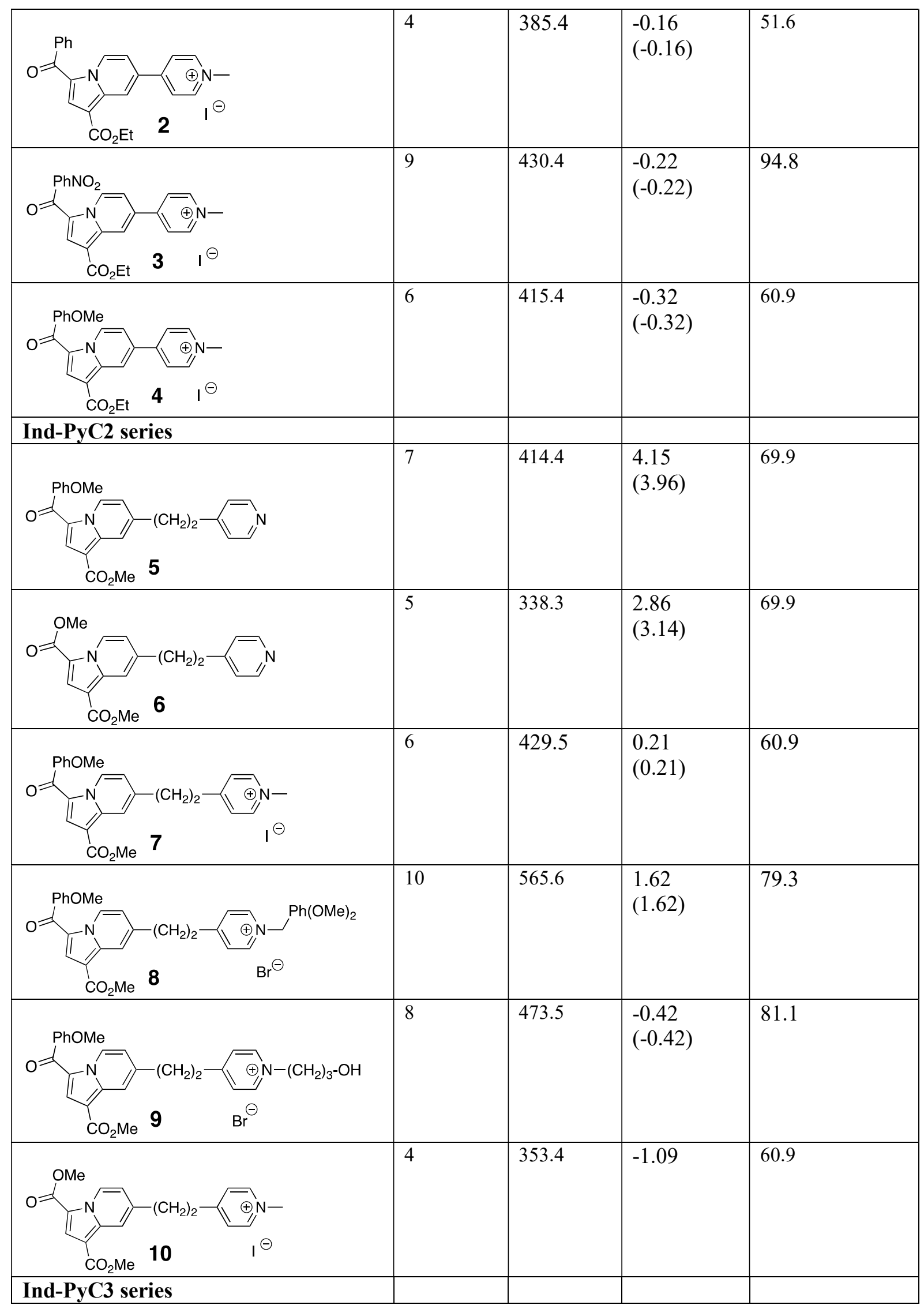




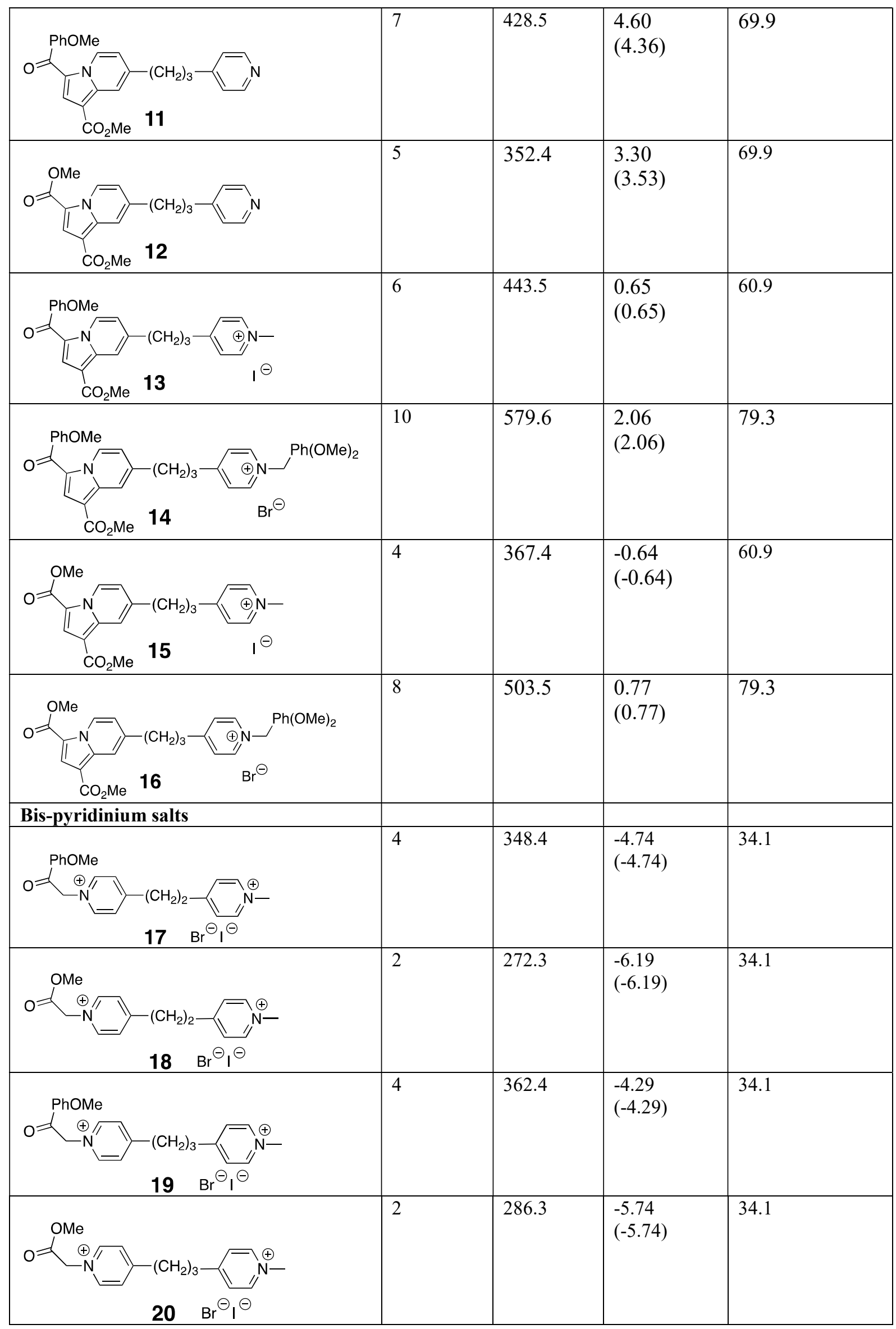


Table 1. ADMET molecular predictors. The calculations have been performed using MarvinSketch 19.9 software (http://www.chemaxon.com). ${ }^{\text {a }}$ There is no $\mathrm{H}$ bond donor site in these molecules; ${ }^{b}$ for LogD calculations, the Consensus option, built on the ChemAxon and Klopman ${ }^{40}$ models and the PhysProp database, was chosen; ${ }^{\mathrm{c}}$ The values are $\mathrm{pH}$ dependent and are given for $\mathrm{pH} 7$

\section{Syntheses}

In the present work, the objective was to prepare a series of $\mathrm{N}$-alkylpyridinium-indolizine hybrids with structural diversity by both playing with the nature of the starting bis-pyridines and with that of the $\mathrm{N}$-alkyl substituents. Two strategies were envisioned to prepare the Nalkylpyridinium-indolizine hybrids, both based on the formation of the indolizine ring through 1,3-dipolar cycloaddition of alkynes with the ylides formed in situ from suitably substituted pyridinium salts as depicted in Scheme 1 (blue part). The first one, already reported ${ }^{29,30}$ for compounds 2-4 of the Ind-PyC0 series, used non-symmetrical bis-alkylated bipyridinium salts as key intermediates which were obtained by controlled mono-methylation of 4,4'-bipyridine, followed by a second alkylation step with diversely substituted iodoacetophenones. To prepare the pyridine analog $\mathbf{1}$, the 4,4'-bipyridine was first alkylated with the iodoacetophenone before cyclisation with ethyl propiolate.

For the Ind-PyC2 and Ind-PyC3 series, with respectively 2 or 3 carbons between the two rings, the molecules mostly differ by the nature of the pyridinium $\mathrm{N}$-alkyl group. It then appeared more time saving to first build the indolizine core, and then to quaternize the resulting pyridineindolizine by using various alkylating agents (Scheme 1).
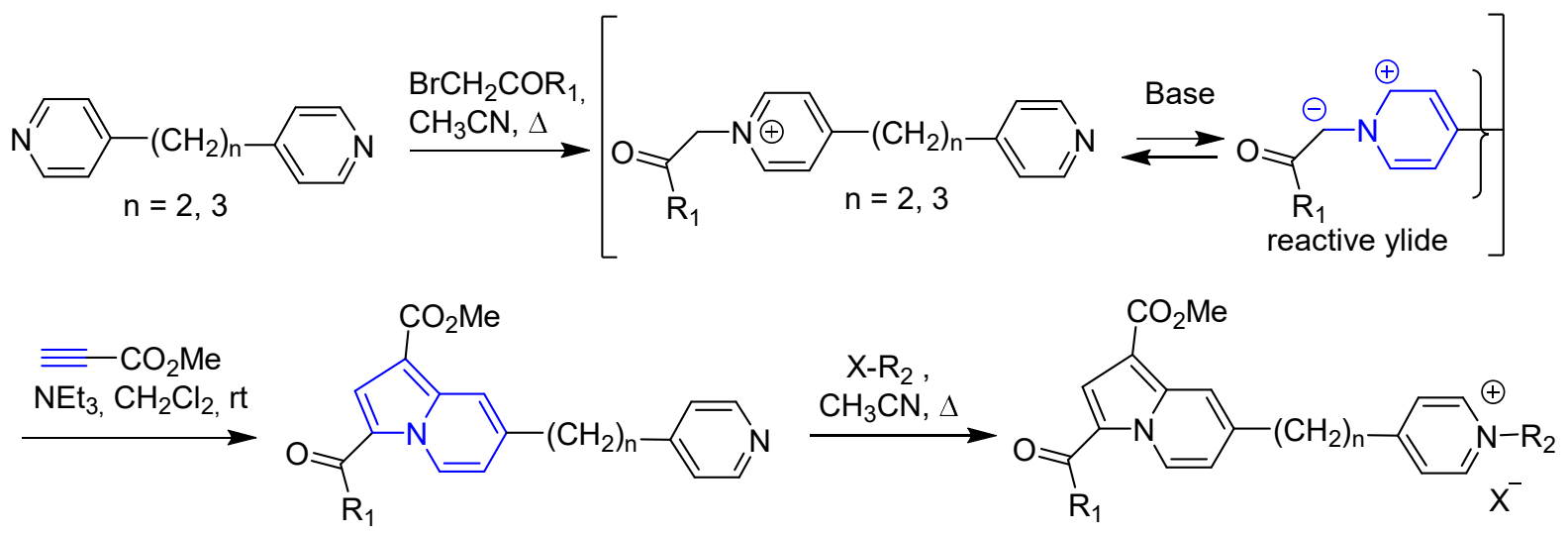

Scheme 1. General route to the N-alkylpyridinium-indolizine hybrids of the Ind-PyC2 and Ind-PyC3 series.

The reaction conditions and yields are collected in Table 2. In most cases, the first alkylation step was performed at $70-80^{\circ} \mathrm{C}$ in $\mathrm{CH}_{3} \mathrm{CN}$ in the presence of 0.9 to 1 equivalent of the alkylating agent (2-bromo- $p$-methoxyacetophenone or methyl 2-bromoacetate), to give the desired monoalkylated product as major compound in medium to excellent yield (30-85\% yields). In some cases, a mixture of mono- and bis-alkylated compounds was isolated and used as such in the next step. Cycloaddition with methyl propiolate, forming the indolizine ring, was then achieved at room temperature in $\mathrm{CH}_{2} \mathrm{Cl}_{2}$ using triethylamine as base to form the reactive ylide. The resulting pyridine-indolizine hybrids were isolated in $40-65 \%$ yields. The final step of reaction with various alkylating agents was done in $\mathrm{CH}_{3} \mathrm{CN}$ to give the pyridinium-indolizine salts in good to excellent yields (60-100\%). 
Table 2. Reaction Conditions for Ind-PyC2 and Ind-PyC3 synthesis.

\begin{tabular}{|c|c|c|}
\hline Compounds & Reaction conditions & yield \\
\hline 5 & $\begin{array}{l}\text { 1) } \mathrm{A}^{\mathrm{a}}, \mathrm{BrCH}_{2} \mathrm{COPh}(p-\mathrm{OMe}), \mathrm{CH}_{3} \mathrm{CN}, 70-80^{\circ} \mathrm{C}, 2 \mathrm{~h} \\
\text { 2) methyl propiolate, } \mathrm{NEt}_{3}, \mathrm{CH}_{2} \mathrm{Cl}_{2}, \mathrm{rt}, 5 \mathrm{~h}\end{array}$ & $51 \%$ \\
\hline 6 & $\begin{array}{l}\text { 1) } \mathrm{A}^{\mathrm{a}}, \mathrm{BrCH}_{2} \mathrm{CO}_{2} \mathrm{CH}_{3}, \mathrm{CH}_{3} \mathrm{CN}, 70-80^{\circ} \mathrm{C}, 3 \mathrm{~h} \\
\text { 2) methyl propiolate, } \mathrm{NEt}_{3}, \mathrm{CH}_{2} \mathrm{Cl}_{2}, \mathrm{rt}, 2 \mathrm{~h}\end{array}$ & $12 \%$ \\
\hline 7 & $5, \mathrm{CH}_{3} \mathrm{CN}, \mathrm{ICH}_{3}, 50^{\circ} \mathrm{C}, 4 \mathrm{~h}$ & $100 \%$ \\
\hline 8 & 5, $\mathrm{CH}_{3} \mathrm{CN}, \mathrm{BrBn}^{\mathrm{c}}, 70-80^{\circ} \mathrm{C}, 3 \mathrm{~h}$ & $77 \%$ \\
\hline 9 & 5, $\mathrm{CH}_{3} \mathrm{CN}, 3$-bromo-1-propanol,70-80 ${ }^{\circ} \mathrm{C}, 20 \mathrm{~h}$ & $50 \%$ \\
\hline 10 & $\mathbf{6}, \mathrm{CH}_{3} \mathrm{CN}, \mathrm{ICH}_{3}, 50^{\circ} \mathrm{C}, 4 \mathrm{~h}$ & $85 \%$ \\
\hline 11 & $\begin{array}{l}\text { 1) } \mathbf{B}^{\mathrm{b}}, \mathrm{BrCH}_{2} \mathrm{COPh}(p-\mathrm{OMe}), \mathrm{CH}_{3} \mathrm{CN}, 70-80^{\circ} \mathrm{C}, 2 \mathrm{~h} \\
\text { 2) methyl propiolate, } \mathrm{NEt}_{3}, \mathrm{CH}_{2} \mathrm{Cl}_{2}, \mathrm{rt}, 2 \mathrm{~h}\end{array}$ & $28 \%$ \\
\hline 12 & $\begin{array}{l}\text { 1) } \mathbf{B}^{\mathrm{b}}, \mathrm{BrCH}_{2} \mathrm{CO}_{2} \mathrm{CH}_{3}, \mathrm{CH}_{3} \mathrm{CN}, 70-80^{\circ} \mathrm{C}, 3 \mathrm{~h} \\
\text { 2) methyl propiolate, } \mathrm{NEt}_{3}, \mathrm{CH}_{2} \mathrm{Cl}_{2}, \mathrm{rt}, 4 \mathrm{~h}\end{array}$ & $30 \%$ \\
\hline 13 & 11, $\mathrm{CH}_{3} \mathrm{CN}, \mathrm{ICH}_{3}, 50^{\circ} \mathrm{C}, 4 \mathrm{~h}$ & $100 \%$ \\
\hline 14 & 11, $\mathrm{CH}_{3} \mathrm{CN}, \mathrm{BrBn}^{\mathrm{c}}, 70-80^{\circ} \mathrm{C}, 3 \mathrm{~h}$ & $100 \%$ \\
\hline 15 & 12, $\mathrm{CH}_{3} \mathrm{CN}, \mathrm{ICH}_{3}, 60^{\circ} \mathrm{C}, 3 \mathrm{~h}$ & $71 \%$ \\
\hline 16 & 12, $\mathrm{CH}_{3} \mathrm{CN}, \mathrm{BrBn}^{\mathrm{c}}, 70^{\circ} \mathrm{C}, 3 \mathrm{~h}$ & $90 \%$ \\
\hline
\end{tabular}

${ }^{\mathrm{a}} \mathbf{A}$ : 1,2-bis(4-pyridyl)ethane; ${ }^{\mathrm{b}} \mathbf{B}$ : 1,3-bis(4-pyridyl)propane; ${ }^{\mathrm{c}} \mathrm{BrBn}$ : 3,5-dimethoxybenzyl bromide.

Three of the pyridine-indolizine intermediates, $\mathbf{6}$ and $\mathbf{1 1}$ and 12, were selected for biological evaluation as neutral analogs. Four bis-pyridinium salts (17-20) were also prepared by controlled mono N-alkylation with methyl iodide, followed by the reaction with bromoacetophenone (the structures are depicted in Table 1).

\section{Biological evaluation}

\subsection{Spectroscopic properties}

The commonly used methods to evaluate cholinesterase inhibition and antioxidant activity are the Ellman's assay and the DPPH assay, respectively. They are both colorimetric spectroscopic assays. The Ellman's method ${ }^{41}$ needs 5,5'-dithio-bis-2-nitrobenzoic acid (DTNB) and acetylthiocholine as alternative substrate of enzyme, and the AChE activity (in presence or absence of compounds) is monitored by the formation of the yellow 5-thio-2-nitrobenzoate that absorbs at $405 \mathrm{~nm}$. For the screening of antioxidant capacity of molecules, the assay is based on the reduction of a purple colored DPPH (2,2-diphenyl-1-picrylhydrazyl) that strongly 
absorbs at $517 \mathrm{~nm}^{42}$. DPPH is a free radical that can react with a hydrogen donating antioxidant molecule. The antioxidant effect is then evaluated by following the decrease of the $517 \mathrm{~nm}$ absorption. Thus, if the molecules to be tested absorb strongly around either 400 or $500 \mathrm{~nm}$, the results of the assay may be biased. The absorption of the tested molecules is also of importance when studying their effect onto amyloid fibril formation by the fluorescence Thioflavin (ThT) assay $^{43,44}$ Indeed, ThT assay is based on the fluorescence of the ThT dye in presence of the characteristic $\beta$-sheet motif of amyloid fibres in formation. Thus, molecules with spectral profiles in the same range as the bound ThT ( $\lambda$ ex at $440 \mathrm{~nm}$ and $\lambda$ em at $480 \mathrm{~nm}$ ) may biased the assay by an inner filter effect and conduct to misleading interpretations ${ }^{45,46}$.

In light of this, we first recorded the UV/Vis absorption of all the molecules to check if their own spectroscopic properties would not interfere with the assays (Table S1). Except for the uncharged hybrid 1, due to their extended conjugation, the Ind-PyC0 molecules strongly absorb around $415 \mathrm{~nm}$, thus making impossible their evaluation with both Ellman's and ThT assays. For all other compounds, maximum UV/Vis absorptions around 325 or $375 \mathrm{~nm}$ are suitable for all the three assays.

\subsection{Antioxidant properties}

Oxidative stress is involved in age related neurodegenerative diseases and in particular in AD. Thus, antioxidants may have positive benefits in reducing or delaying neuronal death. The antioxidant properties of the molecules were evaluated by DPPH radical scavenging. The 1,1diphenyl-2-picrylhydrazyl or DPPH is a stable free radical characterized by a deep violet color, with an absorption band in ethanol solution at $517 \mathrm{~nm}$. In the presence of a molecule that can donate a hydrogen atom, the formation of reduced DPPH is accompanied with the loss of this violet color. Rutin was used as reference. The DPPH inhibition \% which relates to antioxidant activity was calculated at $48 \mu \mathrm{g} / \mathrm{ml}$ drug concentrations (i.e. the concentration for which rutin gives $83.3 \pm 0.1$ inhibition $\%$ in our assay), 188 and $750 \mu \mathrm{g} / \mathrm{ml}$ drug concentrations (Figure 3, Table S2 $)^{47}$. All the molecules have been tested however as indicated in Table S2 some molecules (compounds $\mathbf{1}$ and $\mathbf{3}$ from the Ind-PyC0 series and the uncharged compounds $\mathbf{5}$ and 11) displayed an unacceptable standard deviation due to precipitation issue and are not therefore indicated in the Figure 3.

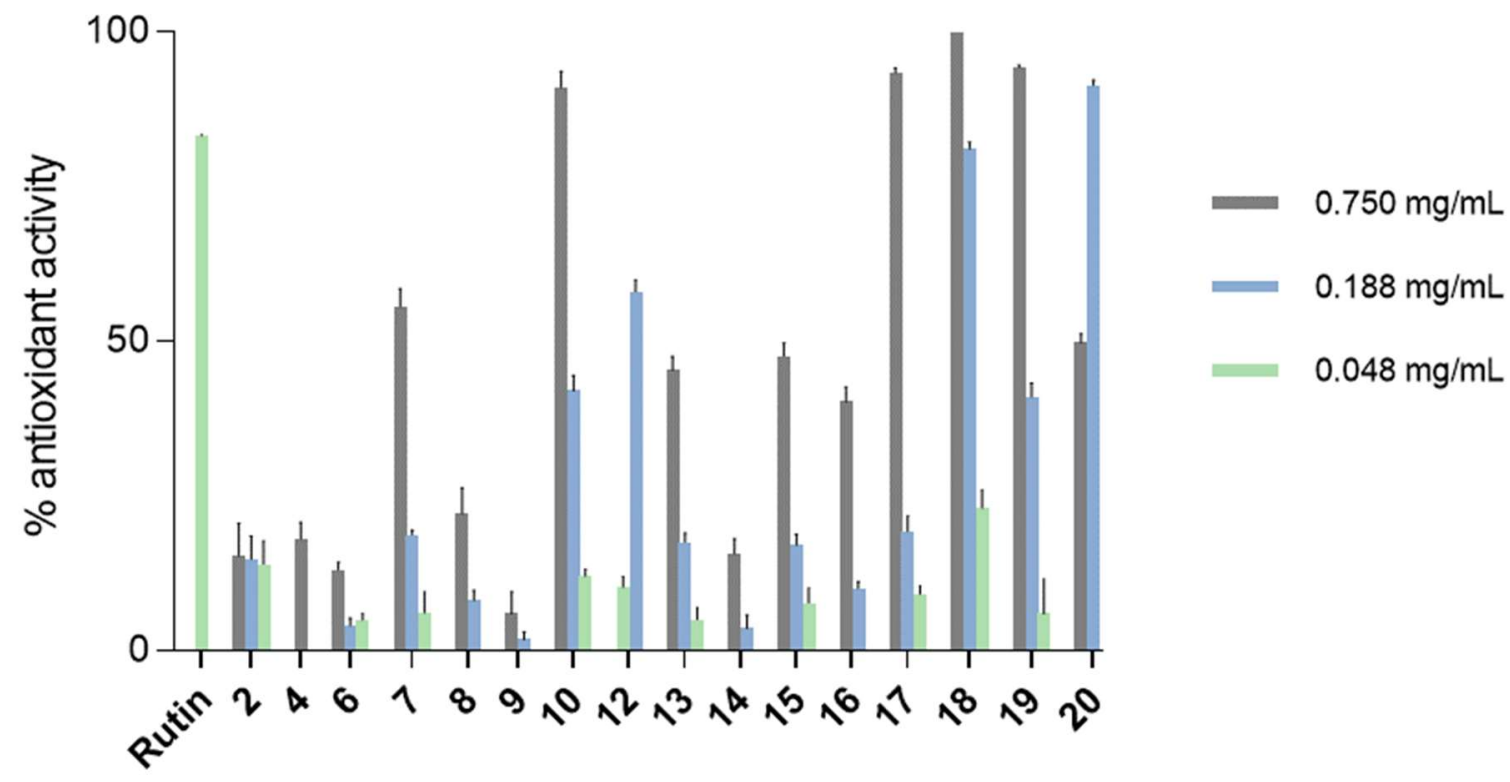

Figure 3. Antioxidant activity (\%) is measured using DPPH assay at $48 \mu \mathrm{g} / \mathrm{ml}$ (green), 188 
$\mu \mathrm{g} / \mathrm{ml}$ (blue) or $750 \mu \mathrm{g} / \mathrm{ml}$ (purple) drug concentrations, rutin was used as reference. All assays were performed in triplicate and each bar value corresponds to the mean $\pm \mathrm{SD}$. Both the values with unacceptable SD and closed to zero are not represented (see Table S2).

Most of the molecules showed no or low activity when dosed at $48 \mu \mathrm{g} / \mathrm{ml}$, except with the bispyridinium salt 20, significantly active at that concentration (around 50\% inhibition). However, rising the drug concentration up to $750 \mu \mathrm{g} / \mathrm{ml}$ led to a significant increase in efficiency for most compounds, and in particular the bis-pyridinium 17-19 showed up to $>90 \%$ inhibition. Among the hybrids, the neutral compound 12 seemed promising with near $60 \%$ inhibition at $188 \mu \mathrm{g} / \mathrm{ml}$, but solubility issues prevented correct measurements at higher concentration. As for 10, it showed the highest antioxidant properties (about $90 \%$ inhibition) at $750 \mu \mathrm{g} / \mathrm{ml}$ for the IndPyCx series. Note that we observed similar trends with the previously described symmetrical analogs, bis-pyridinium salts showing better activity compared to bis-indolizines (compare 1' and ' ' series vs 3' and 4' series, see Table S5).

\subsection{Cholinesterase inhibition}

The cholinesterase activity was evaluated using the Ellman's spectrophotometric method ${ }^{41}$ against electric eel $\mathrm{AChE}$ (eeAChE) and equine butyrylcholinesterase (eqBChE), and selected compounds have been further tested against the human enzymes (hAChE and $\mathrm{hBChE}$ ). The data are collected in Table 3 (see also the corresponding Prism data and curves in SI).

Table 3. Cholinesterase inhibition. a,b

\begin{tabular}{|c|c|c|c|c|c|c|c|}
\hline $\begin{array}{l}\text { Ind- } \\
\text { PyC2 }\end{array}$ & & 6 & 7 & 8 & 10 & & 9 \\
\hline $\begin{array}{l}\text { ee } \\
\text { AChE }\end{array}$ & & Inact. $^{c}$ & $4.4 \pm 0.5$ & Inact. $^{c}$ & $5.4 \pm 0.1$ & & $2.0 \pm 0.4$ \\
\hline eqBChE & & Inact. $^{\mathrm{c}}$ & $17.5 \pm 8.2$ & Inact. $^{c}$ & $55.4 \pm 2.3$ & & $8.8 \pm 3.5$ \\
\hline hAChE & & nd & $6.6 \pm 1.1$ & nd & $37.1 \pm 4.1$ & & $8.0 \pm 0.9$ \\
\hline $\mathrm{hBChE}$ & & nd & nd & nd & nd & & nd \\
\hline $\begin{array}{l}\text { Ind- } \\
\text { PyC3 }\end{array}$ & 11 & 12 & 13 & 14 & 15 & 16 & Donepezil $^{\mathrm{e}}$ \\
\hline eeAChE & Inact. $^{c}$ & Inact. $^{c}$ & $2.6 \pm 0.6$ & $>10 \mu \mathrm{M}^{\mathrm{d}}$ & $7.9 \pm 0.6$ & $2.7 \pm 0.6$ & $0.052 \pm 0.007$ \\
\hline eqBChE & Inact. $^{\mathrm{c}}$ & Inact. $^{c}$ & $7.5 \pm 3.4$ & $4.8 \pm 1.3$ & $72.1 \pm 15.9$ & $7.3 \pm 1.2$ & $6.0 \pm 1.7$ \\
\hline $\mathrm{hAChE}$ & nd & nd & $3.3 \pm 0.7$ & nd & $4.0 \pm 0.9$ & $9.4 \pm 2.5$ & $0.029 \pm 0.005$ \\
\hline $\mathrm{hBChE}$ & nd & nd & $38.9 \pm 14.0$ & nd & $>100 \mu \mathrm{M}$ & nd & $9.2 \pm 5.6$ \\
\hline
\end{tabular}

${ }^{\mathrm{a}} \mathrm{IC}_{50}$ values in $\mu \mathrm{M}$ are expressed as mean \pm standard error of three independent experiments performed in triplicates; ${ }^{b}$ For easier comparison of $\mathrm{C} 2$ versus $\mathrm{C} 3$ series, the molecules containing the same substituents are represented in the same column; ${ }^{\mathrm{c}}$ the molecules indicated as inactive did not show significant activities during a first rapid screening at $4 \mu \mathrm{M}$ (Figure S2 to S5); ${ }^{\mathrm{d}}$ formation of aggregates at higher concentrations in presence of eeAChE; ${ }^{\mathrm{e}}$ Donepezil is used as control (Table S4 for curves). 
Our goal being to select molecules that would significantly inhibit cholinesterases, a rapid screening of all series was first performed at $4 \mu \mathrm{M}$ against eeAChE and eqBuChE (see Figure $\mathrm{S} 2$ to S5). Only the molecules that inhibited at least $50 \%$ of the $\mathrm{ChE}$ activity at this micromolar concentration were then evaluated in a larger concentration range to precisely calculate $\mathrm{IC}_{50}$ values. The data are collected in Table 3 (see also Table S3 for the $\mathrm{IC}_{50}$ curves).

The already mentioned strong UV-Vis absorbance of the Ind-PyC0 series molecules, along with their lower solubility in water, prevented their study in a large range of concentrations, and the promising effects obtained in the $4 \mu \mathrm{M}$ screenings, especially for 2 and $\mathbf{3}$ against eeAChE, could not be confirmed (see Figures S2). As for the bis-pyridinium salts 17-20, they did not show any significant inhibition properties against the two enzymes at $4 \mu \mathrm{M}$ (Figure S5). Similarly, the uncharged pyridine-indolizines $(6,11$ and 12) are inactive against both enzymes (Figure S4). At the opposite, as expected, most of the corresponding symmetrical cationic pyridine-indolizine hybrids were active at $4 \mu \mathrm{M}$. Unlike what was previously observed with most of bis-indolizines (see Table S5) that easily form aggregates in aqueous solutions, the generally better solubility of the pyridinium-indolizine hybrids allowed their evaluation in a larger concentration range.

Thus, the cationic hybrids displayed micromolar $\mathrm{IC}_{50}$, with a slight selectivity for eeAChE vs eqBChE (Table 3), except 10 and its analog 15 which showed the highest selectivity being 10 times more active against ee $\mathrm{AChE}$ compare to eqBChE ${ }^{48}$.

The Ind-PyC3 molecules containing the 3-p-methoxybenzoyl group appeared more active against the two enzymes than their Ind-PyC2 analogs (compare 13 and 14 with $\mathbf{7}$ and 8, respectively). This effect may be related to the better flexibility of the propyl linker compared to the shorter ethyl one. Concerning the eeAChE inhibition, the pyridinium-indolizine hybrid $\mathbf{8}$ was the only inactive hybrid. This hybrid bears the lipophilic bulky $\mathrm{N}$-dimethoxybenzyl group along with the 3-p-methoxybenzoyl substituent. Its Ind-PyC3 analog $\mathbf{1 4}$ displayed more interesting activities against both enzymes, however a closer look to the curves and Prism calculations (Table S3) showed that its limited solubility in presence of eeAChE at higher concentrations than $10 \mu \mathrm{M}$ leads to a decreased R-squared compared to the other tested molecules. Compound 16, analog of $\mathbf{1 4}$ in which the 3-p-methoxybenzoyl is replaced by the smaller size methyloxycarbonyl group, exhibited a good activity against both eeAChE $\left(\mathrm{IC}_{50}=\right.$ $2.7 \mu \mathrm{M})$ and eqBChE $\left(\mathrm{IC}_{50}=7.3 \mu \mathrm{M}\right)$ without any apparent solubility limitation.

Due to the high costs of the human cholinesterases, a few active molecules were then chosen for further evaluation (Table 3, and Figure $\mathrm{S} 6$ for $\mathrm{IC}_{50}$ curves). For most tested compounds, $\mathrm{IC}_{50}$ against $\mathrm{hAChE}$ remained in the same micromolar range, except for $\mathbf{1 0}$ that lost activity with $\mathrm{IC}_{50}>30 \mu \mathrm{M}$. for hAChE. Two molecules, 13 and $\mathbf{1 5}$, that only differ by the nature of the substituent at position 3 of the indolizine ring, were also tested against $\mathrm{hBChE}$. Indeed, they were both active on hAChE with similar $\mathrm{IC}_{50}$ values around $4 \mu \mathrm{M}$, and only 13 showed an activity against eqBChE. Compound $\mathbf{1 3}$ showed a strong decrease in efficacy ( $\mathrm{IC}_{50} / 5$ ) against $\mathrm{hBChE}$, while 15 remain inactive even at $100 \mu \mathrm{M}$ concentration. The selectivity of $\mathbf{1 5}$ for AChE vs BChE was then confirmed on human enzymes.

The indolizine derived molecules reported in this study contain at least one carboxylic ester function. Considering the hydrolase activity of the tested enzymes, we wondered if these esters could be substrates of the enzymes ${ }^{49}$. To answer this question, the behavior of $\mathbf{1 5}$, containing two methyl esters groups at positions 1 and 3 of the indolizine ring, was studied in presence of 
either hAChE or hBChE and of their respective substrates (acetyl- or butyrylthiocholines). The reactions were monitored by HPLC using a diode array detector, and after one day of reaction the organic compounds were extracted from the $\mathrm{pH} 8$ buffer by dichloromethane. After evaporation of the organic phases, the residues were dissolved in deuterated chloroform to perform ${ }^{1} \mathrm{H}$ NMR analysis. Neither retention time nor absorbance values appeared modified on the HPLC chromatograms. The NMR data corresponded to a mixture of the starting diester 15 and of thiochloline (Figure S1). However, the integration of the peaks at $3.95 \mathrm{ppm}$ corresponding to the two $\mathrm{OCH}_{3}$ appeared slightly smaller than expected for the diester, which may indicate the presence of a small amount of partly hydrolyzed 15. The close proximity of the two $\mathrm{OCH}_{3}$ peaks did not allow the identification of the ester that was preferentially hydrolyzed. The dichloromethane extraction from the $\mathrm{pH} 8$ buffer used to perform the enzymatic reaction constituted a limitation to this study as the hydrolysis of $\mathbf{1 5}$ would give either a zwitterion (mono-hydrolysis) or a negatively charged diacid (bis-hydrolysis), that would be difficult to extract from the basic medium.

However, this study clearly showed that after one day of reaction, a significant amount of diester 15 was still present in solution, but a partial hydrolysis could not be ruled out from the NMR analysis.

\subsection{Docking calculations}

Docking calculations were performed to compare the possible binding modes of compounds $\mathbf{1 3}$ and 15 within the active sites of the two human cholinesterases, Indeed, whilst both are active as inhibitors of $\mathrm{AChE}$ (eel or human), they showed a different behavior on $\mathrm{BChE}$ (equine or human).

It is challenging to design a good inhibitor that is active on both $\mathrm{hAChE}$ and $\mathrm{hBChE}$ enzymes, as they differ considerably in size (hAChE binding site is much smaller than hBChE) and in composition (residues W286, V294, Y124, Y337, F297 in hAChE are respectively A277, P285, Q119, A328 and V288 in hBChE).

Compounds 13 and 15 show Glide docking scores respectively equal to -11.3 and $-9.3 \mathrm{kcal} / \mathrm{mol}$ in $\mathrm{hAChE}$, and $-9.1 \mathrm{kcal} / \mathrm{mol}$ and $-8.5 \mathrm{kcal} / \mathrm{mol} \mathrm{in} \mathrm{hBChE}$. These theoretical affinity patterns are in agreements with experimental $\mathrm{IC}_{50}, 13$ being more active than 15 with-on both enzymes (Table 3).

In the hAChE active site (Figure 4), the best pose of $\mathbf{1 3}$ has its pyridinium moiety oriented towards the bottom of the catalytic site, in the immediate vicinity of E202 and of the catalytic serine S203 (Figure 4b). It is stabilized by $\pi$-stacking interactions with Y337 and W86 residues, and its benzoyl and indolizine groups interact with W286. This binding mode is fully conserved among the 20 best poses of 13, probably driven by the stabilizing interaction with E202 negative charge. Thus, 13 is not in a suitable position for hydrolysis by the hAChE enzyme. -Compound 15 possesses a smaller methyl ester group replacing the benzoyl group of 13; its best pose is oriented inversely compared to $\mathbf{1 3}$, with the pyridinium group towards the entrance of the cavity, and the methyl ester group at position 3 facing the catalytic triad at the bottom, allowing a possible hydrolysis (Figure 4a). The indolizine moiety is surrounded by residues W86, Y337, F338 and the pyridinium moiety is in $\pi$-stacking interactions with W286. Due to the smaller size of 15, more heterogeneity can be observed among the binding poses: a binding pose, with the pyridinium moiety oriented towards the catalytic pocket and a salt bridge with E202, shows a close docking score of $-8.8 \mathrm{kcal} / \mathrm{mol}$. These data are consistent with the similar activity observed for both 13 and 15 with hAchE. 
In the $\mathbf{h B C h E}$ binding site, $\mathbf{1 3}$ adopts preferentially a binding pose with its pyridinium moiety inserted at the bottom of the site, close to the catalytic H438; the charge is stabilized by the hydroxyles of tyrosines Y332,-and Y440[c1], and by three carbonyl groups of residues A328 G78 H438 (Figure 4d). Residue W82 provides a favorable $\pi$-stacking interaction to the pyridinium group. The methyl ester moiety is located less than $5 \AA$ to the catalytic S198, and we can hypothesize that this compound adopts a closely-related binding mode to the natural substrate butyrylcholine. This binding mode is very conserved among the twenty best poses of 13. The best pose of $\mathbf{1 5}$ shows its pyridinium moiety oriented towards the entrance bottom of the cavity[e2],-where it is stabilized by the carbonyl oxygen of A328[AT3][C4] (Figure 4c). The methyl ester at position 1 is in a perfect position for hydrolysis by S198.(less than $3.5 \AA$ ).

Compounds 13 and 15 show a conserved orientation of their pyridinium moieties within the hBChE pocket, but an inversed positioning of this group in Contrary to the binding modes within the $\mathrm{hBChE}$ pocket, 13 and 15 have their pyridinium moieties not superposed in $\mathrm{hAChE}$ : $\mathbf{1 3}$ has its pyridinium group towards the CAS site, whereas $\mathbf{1 5}$ has its pyridinium group towards the entrance of the cavity. Residue W286, which is an alanine in hAChE, is in pi-stacking interaction with the benzoyl substituent of $\mathbf{1 3}$ and the pyridinium of $\mathbf{1 5}$.

Concerning the diester 15, it is worth noting that with both enzymes, one methyl ester is in good position for hydrolysis, in agreement with the NMR study analysis. 


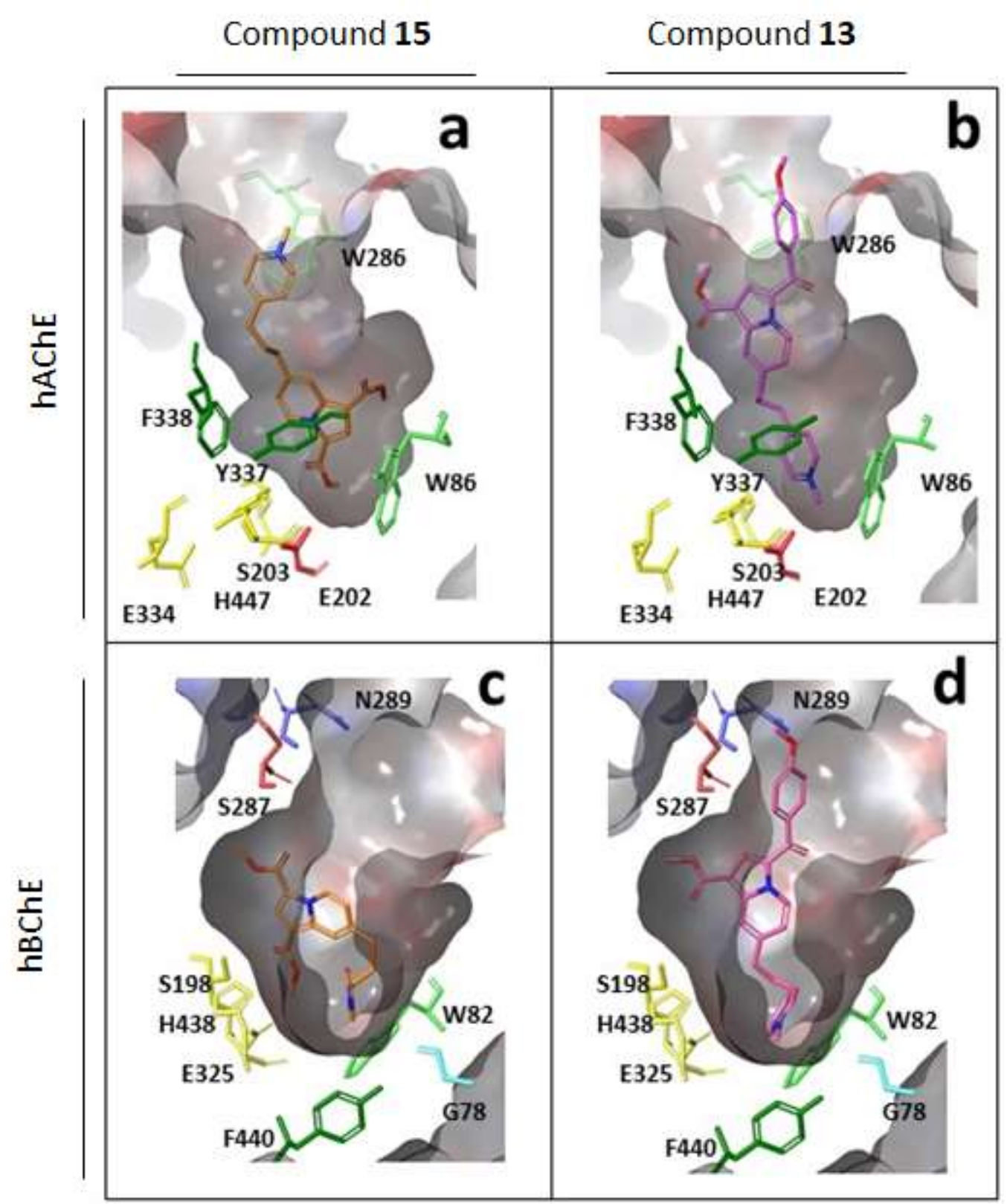




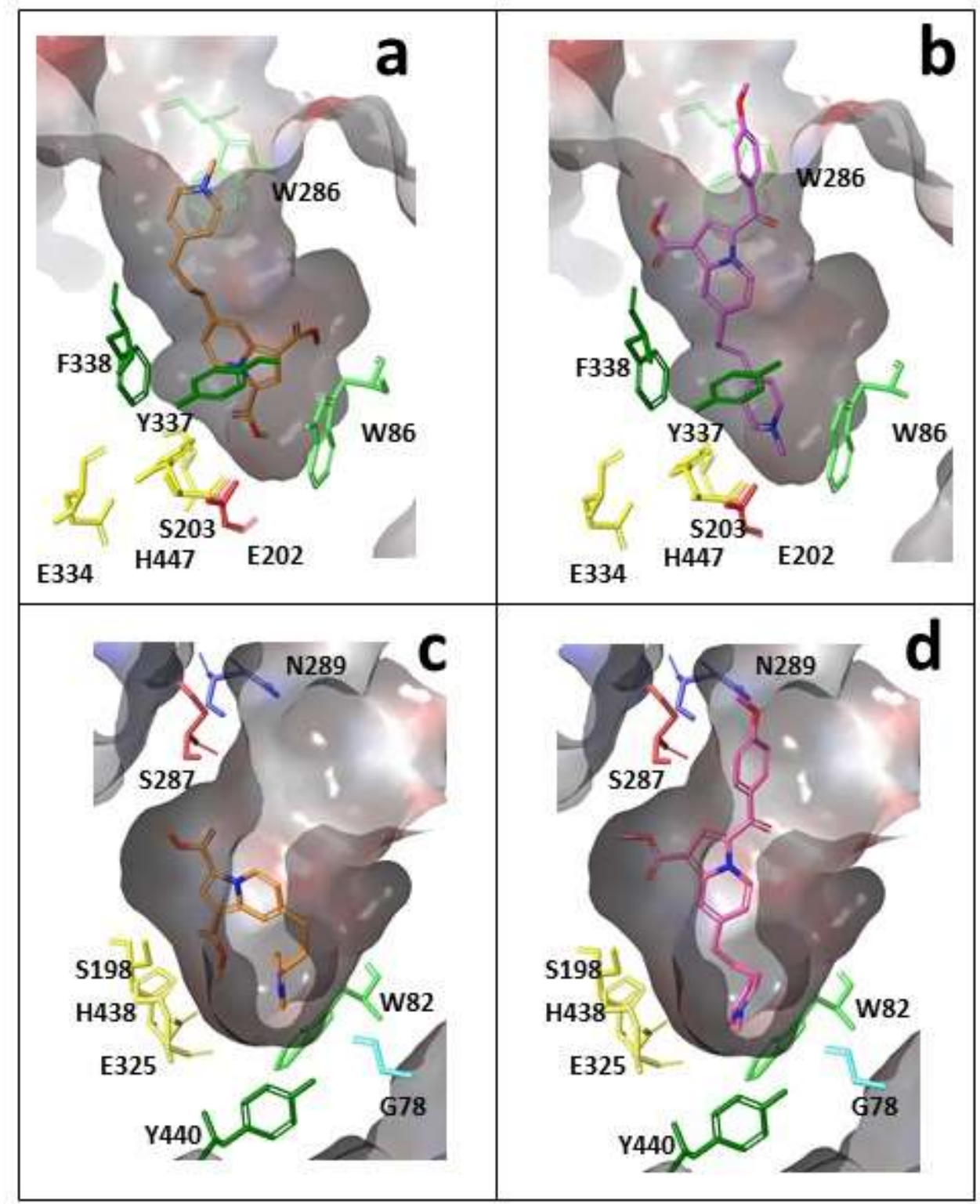

Figure 4. In a and $\mathrm{b}$ are illustrated the binding site of hAChE with respectively docked $\mathbf{1 5}$ and 13. In $\mathrm{c}$ and $\mathrm{d}$ are respectively drawn the best docked poses of $\mathbf{1 5}$ and $\mathbf{1 3}$ in the hBChE binding pocket. The catalytic residues are in yellow.

\subsection{Amyloid fibrillation inhibition}

To monitor the effect of a molecule on the amyloid fibrillation process (amyloid fiber formation), the thioflavin-based fluorescence assays are generally used because of the thioflavin T (ThT) fluorescence is highly sensitive to the $\beta$-sheet motifs of fibers. Upon binding 
to fibers, ThT displays a red shifted emission allowing the selective detection of $\beta$-sheet rich structures such as fibers. We used here two models of amyloid peptides both derived from the tau protein sequence (Figure 5).

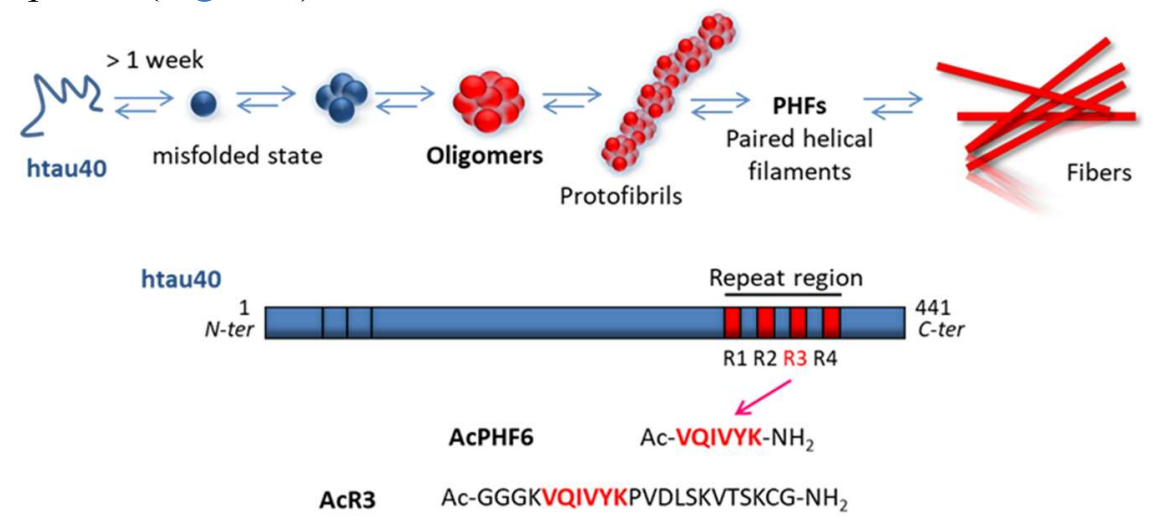

Figure 5. Tau fibrillation process (in red beta-sheet containing species), and the sequences of the two tau models used in this study.

The AcPHF6 model is a short 6 amino-acid length peptide corresponding to the core of tau fibrils ${ }^{34}$. Its fibrillation is much faster than those of tau protein or amyloid peptides that can take days, and is well adapted for a first screening of a set of molecules by ThT fluorescence assays. We already set up in previous works a such screening in microplates to study a series of aurones ${ }^{31}$. In addition, we used a longer peptide derived from the R3 repeat tau region, AcR3, which has been developed in our lab (unpublished data). The studies were performed in phosphate buffer, and we measured the inhibition of the ThT fluorescence signal in presence of the Ind-PyCx and BisPy series at a $100 \mu \mathrm{M}$ concentration corresponding to a $1 / 1$ ratio with the amyloid peptide (Figure 6). AcR3 peptide as tau peptide in vitro needs heparin as fibrillation inducer, and $10 \mu \mathrm{M}$ of heparin corresponding to a $0.1 / 1$ ratio with the amyloid peptide was used.
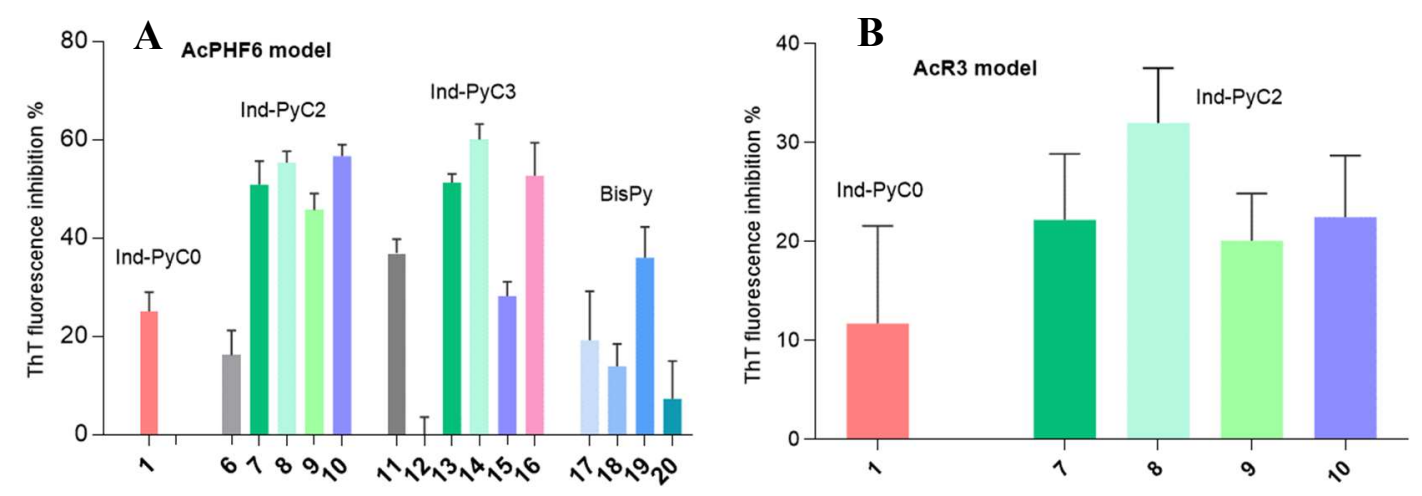

Figure 6. ThT assays on both AcPHF6 (A) and AcR3 (B) models of amyloid fibers $\left(\lambda_{\text {exc }}=440\right.$ $\left.\mathrm{nm}, \lambda_{\mathrm{em}}=480 \mathrm{~nm}\right)$. The results are expressed as the inhibition $\%$ of ThT fluorescence using a ratio compound/model of $1 / 1$ (100 $\mu \mathrm{M}$ concentration). The errors represent the SEM of three independent experiments performed in triplicates.

As shown in figure 6A, most of the Ind-PyC2 and Ind-PyC3 hybrids, displayed some activities on AcPHF6 model. The BisPy references 17-20 or the uncharged compound 6 and 12, were significantly less efficient. The length of the $\mathrm{Cx}$ linker did not seem to play an important role 
as similar activities were observed with both Ind-PyC2 and Ind-PyC3 series. At the first look, the nature of the substituents carried by each hybrid did not seem to be important either. We decided to go further and we chose to evaluate the four most active Ind-PyC2 compounds (710) along with the Ind-PyC0 1 on the longer peptide model AcR3. The inhibition efficiency has been divided at least by a factor two.

It is noteworthy that inhibition of fluorescence in ThT assays does not necessarily mean inhibition of amyloid aggregation process. Indeed, displacement of the bound ThT by the tested compounds may also occur. Thus, we recorded the emission spectrum of a solution of preformed AcR3 fibers in the presence of ThT right after adding the compounds of the IndPyC2 series (Figure 7A). For all of them (in addition to 1), no decrease of ThT signal at 480 nm was observed.

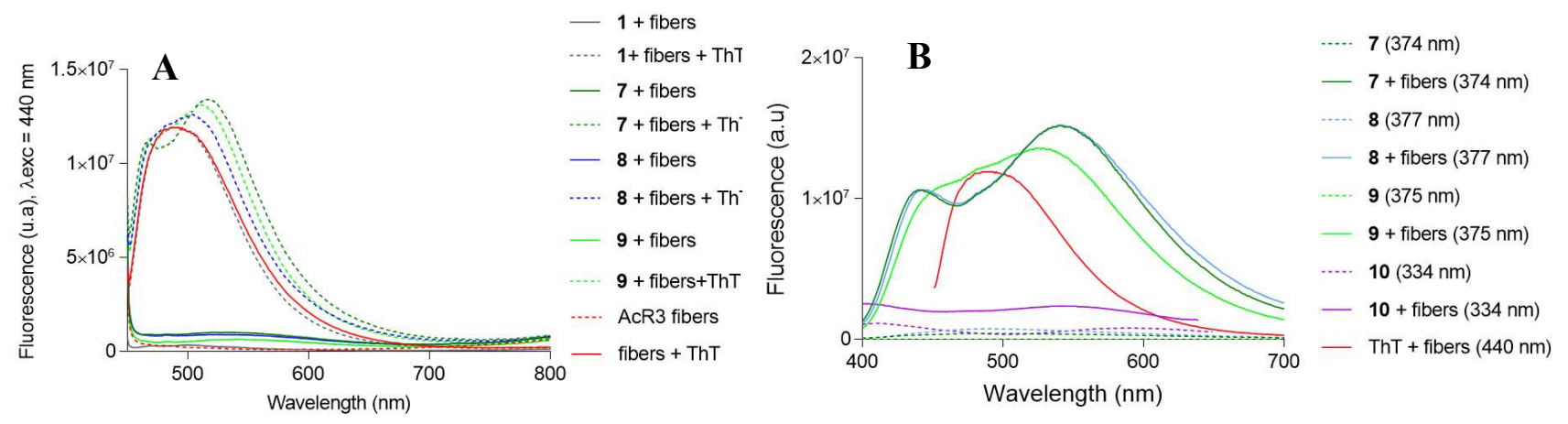

Figure 7. (A) ThT displacement assay. The excitation wavelength is $440 \mathrm{~nm}$. The ratio compound/ThT is $10 / 1(100 / 10 \mu \mathrm{M})$ and the AcR3 fibers have been prepared from $100 \mu \mathrm{M}$ of peptide in presence of ThT. (B) Fluorescence emission of Ind-PyC2 compounds $(100 \mu \mathrm{M})$ alone and in presence of $100 \mu \mathrm{M}$ of pre-formed fibrils. The excitation wavelength corresponds to their absorbance maximum (value in parentheses); ThT in presence of fibers is used for comparison.

This observation is in favor of an inhibitory effect on the fiber formation in ThT assay above (Figure 6) even if it remains moderate at the high $100 \mu \mathrm{M}$ concentration used. The slight increase of fluorescence observed in Figure 7A when adding the Ind-PyC2 compounds on ThT preformed AcR3 fibrils could be explained by a close interaction with fibrils. This is confirmed for the charged Ind-PyC2 series which in presence of preformed AcR3 fibers show an intensive fluorescence emission when excited at their absorbance maximum while they are hardly no intrinsically fluorescent alone (Figure 7B). Compound 10, the only of the series with ester groups on its indolizine part ( 7 being its analog with methoxybenzyl group), is exception to the rule. Interestingly, analogs 14 and 16 from the Ind-PyC3 series have the same behavior (Figure S7), 16 with ester groups do not show a significative emission in presence of AcR3 fibers in contrast to 14, suggesting the importance of the benzyl substituent onto the indolizine part for a greater interaction with fibers.

Note that in the Ind-PyC0 series only the uncharged compound $\mathbf{1}$ could have been evaluated by ThT assay (Figure 6). Indeed, the strong fluorescence of compounds $\mathbf{2}$ and $\mathbf{4}$ in the wavelength range of bound ThT fluorescence emission did not permit their evaluation (Figure S8). Regarding the non-fluorescent Ind-PyC0 3 as the others from the series its strong absorptive property at $440 \mathrm{~nm}$ (excitation wavelength of the assay) acts as an inner filter and is responsible of the ThT fluorescence extinction observed in the assay (Figure S9). 
Thus, to study the interaction of all Ind-PyC0 series, we used circular dichroism spectroscopy, CD providing structural information of amyloid peptides during the fiber formation process. CD spectrum of AcR3 peptide in presence of phosphate buffer and heparin as fibrillation inducer displayed after less than $24 \mathrm{~h}$ at $37^{\circ} \mathrm{C}$ a typical profile of peptide with a high fraction of $\beta$-sheet structures characterized by a broad negative shoulder at around $218 \mathrm{~nm}$ (Figure 8, red color). No significative difference was noticed when compounds 1-4 were added to the fibrillation mixture (Figure 8A) attesting that compounds of Ind-PyC0 series did not impede the formation of $\beta$-sheet structures (note that the positive shoulder of $\beta$-sheet profile under 200 $\mathrm{nm}$ cannot be observed due to the strong absorption of DMSO used for the dilution of compounds). These results tend to show that 1-4 do not inhibit fibers formation, at least the formation of $\beta$-sheet-rich structures.
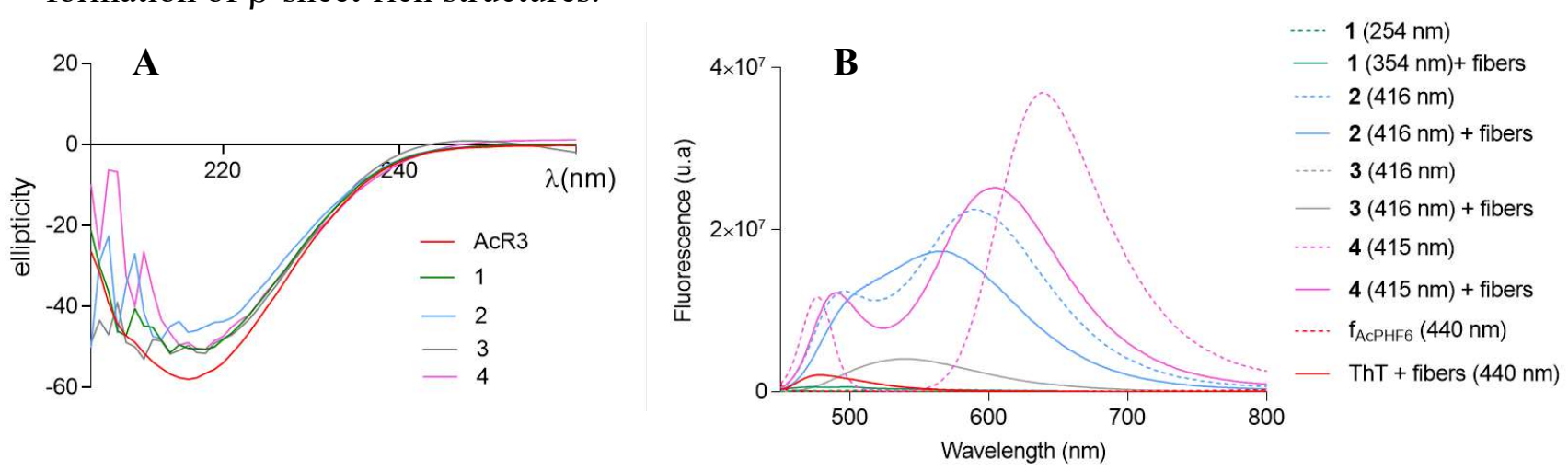

Figure 8. (A) CD spectra obtained after a $24 \mathrm{~h}$ incubation at $37^{\circ} \mathrm{C}$ of $\mathrm{AcR} 3$ at $100 \mu \mathrm{M}$, alone (red) or in presence of $100 \mu \mathrm{M}$ of Ind-PyC0 series 1 to 4. (green, blue, grey and pink). $10 \mu \mathrm{M}$ heparin is used as fibrillation inducer. (B) Fluorescence emission of Ind-PyC0 series $(100 \mu \mathrm{M})$ alone and in presence of $100 \mu \mathrm{M}$ of pre-formed AcPHF6 fibrils. The excitation wavelength corresponds to their absorbance maximum (value in parentheses); $10 \mu \mathrm{M}$ ThT in presence of fibers is used for comparison.

Then, we recorded their fluorescence in presence of preformed fibers as above for the IndPyC2 series (Figure 7B). We observed for the most fluorescence compounds 2 and $\mathbf{4}$ an increase of their fluorescence maximum with a slight red shift in presence of fibers (Figure 8B). Such modification in the emission spectra may be explain by a close interaction with fibers.

More interestingly, among the non-fluorescent compounds $\mathbf{1}$ and 3, $\mathbf{3}$ showed a fluorescence light-up in presence of AcPHF6 fibers whereas 1 not (Figure 9A). In addition, the fluorescence intensity is much higher compared to the signal of the bound ThT dye at the same concentration.
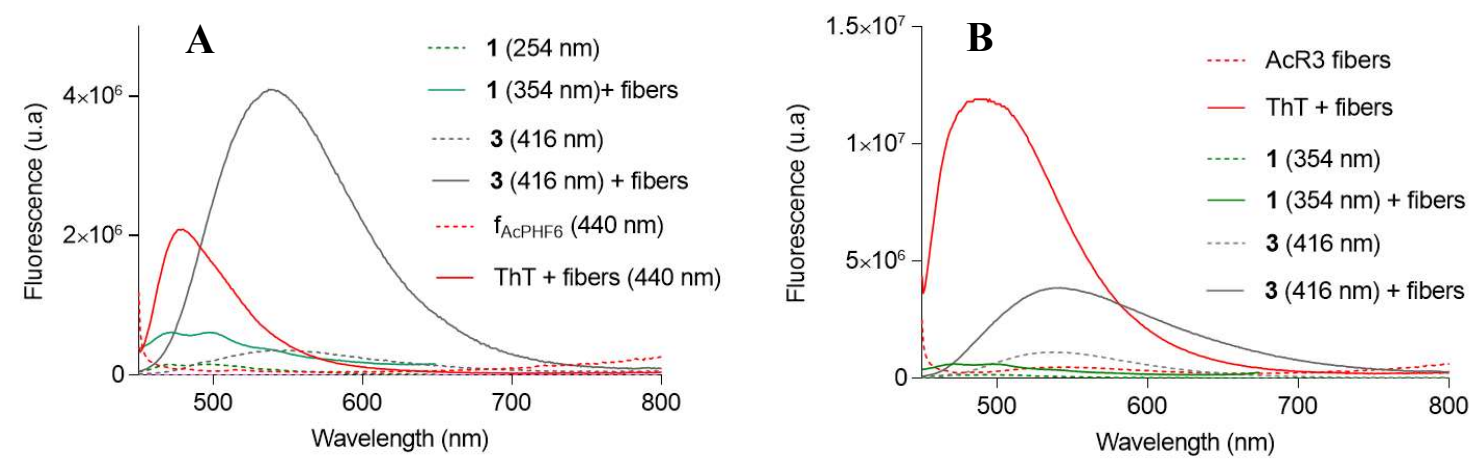
Figure 9. Fluorescence emission of compounds 1 and $\mathbf{3}(100 \mu \mathrm{M})$ alone and in presence of 100 $\mu \mathrm{M}$ of pre-formed AcPHF6 fibrils (A) and $100 \mu \mathrm{M}$ of pre-formed AcR3 fibrils (B). The excitation wavelength corresponds to their absorbance maximum (value in parentheses); $10 \mu \mathrm{M}$ ThT in presence of fibers is used for comparison.

The same response is observed, to a less extent, in the case of AcR3 fibers (Figure 9B and Figure S10). The nitro group of $\mathbf{3}$ could explain this particular behavior. Further study is needed but 3 could be of interest as reporter dye of fibrillation. The fluorescence of $\mathbf{3}$ being red-shifted in comparison to ThT ( $550 \mathrm{~nm}$ vs $480 \mathrm{~nm}$ ), it could allow screening of a wider range of potential inhibitors.

\section{Conclusion}

In the course of this study in the field of Alzheimer and other amyloidogenic diseases, we have synthesized and evaluated a series of 20 molecules, non symetrical bis-pyridinium salts and pyridinium-indolizine hybrids. The molecules were tested for their antioxidant properties by using DPPH assay, as inhibitors of $\mathrm{AChE}$ and $\mathrm{BuChE}$, and for their possible interference with amyloid fibrillation using tau peptide models. The hybrids are constituted of an indolizine core linked to a pyridinium pendant, and differ by the length of the linker, with 0,2 or 3 methylene units (Ind-PyC0, Ind-PyC2 and Ind-PyC3 respectively). The substituent at position 3 of the indolizine and on the heterocyclic pyridine nitrogen were also varied. None of the hybrids showed significant activity on the three targets, i.e. antioxidant activity (DPPH inhibition \%> 50 at $48 \mu \mathrm{g} / \mathrm{mL}$ ), hChE inhibition $\left(\mathrm{IC}_{50}<10 \mu \mathrm{M}\right.$ ) and inhibition of amyloid fiber formation. Moreover, no really difference of activity between the Ind-PyC2 and Ind-PyC3 series has been revealed. Both are only moderate inhibitors of amyloid fibers formation, and moderate antioxidative compounds. Nevertheless, most of the positively charged molecules from these two series are active on both eeAchE and $\mathrm{hChE}$ at micromolar range, and the few that showed eqBChE activity lose it on human. As for the Ind-PyC0 series, it showed a significantly different behavior from the other two series. Both their solubility problem (prone to aggregate in water solution) and their spectral properties did not allow their study as cholinesterase inhibitors nor as fibers inhibitors. Nevertheless, in the amyloid fiber context, fluorescence and $\mathrm{CD}$ experiments revealed that if they are not inhibitors of fibrillation process, the charged compounds from this series, in particular the nitro derived $\mathbf{3}$, could have interesting fluorescence properties to report amyloid fiber formation.

\section{Material and methods}

\section{Synthesis}

NMR spectra were recorded at room temperature in $5 \mathrm{~mm}$ tubes on a Bruker AC $400 \mathrm{MHz}$ spectrometer (NMR facility, PCN-ICMG, Grenoble). Chemical shifts $(\delta)$ are reported in parts per million (ppm) from low to high field and referenced to residual non-deuterated solvent relative to $\mathrm{Me}_{4} \mathrm{Si}$. Standard abbreviations for multiplicity were used as follows: $\mathrm{s}=$ singlet; $\mathrm{d}=$ doublet; $\mathrm{t}=$ triplet; $\mathrm{m}=$ multiplet. High resolution mass sectrometry (HRMS) was carried out on a Bruker UHR-Q-TOF MaXis-ETD (Time of Flight) mass spectrometer using ElectroSpray Ionisation (ESI) in Institut de Chimie Organique et Analytique (CBM-ICOA) in Orleans (France). 
The N-alkylpyridinium-indolizines 1-4 of the Ind-PyC0 series ${ }^{29,30}$ and the bis-pyridinium salt $17^{50}$ have already been described.

\section{Ind-PyC2 series}

Methyl 3-(p-methoxybenzoyl)-7-[2-(4-pyridinyl)ethyl] indolizine-1-carboxylate (5)

This compound was prepared in two steps from ,2-bis(4-pyridyl)ethane:

\section{1) N-Alkylation}

1,2-Bis(4-pyridyl)ethane (504 mg, $2.7 \mathrm{mmol}$ ) was dissolved in $\mathrm{CH}_{3} \mathrm{CN}$ (7 mL). 2-Bromo-pmethoxyacetophenone (1 eq.) was added and the solution was stirred at $70-80^{\circ} \mathrm{C}$ for $2 \mathrm{~h}$. The yellow precipitate was filtrated and dried under vacuum to give pure 1-(2-(4-Methoxyphenyl2-oxoethyl)-4-[2-(4-pyridinyl)ethyl]pyridinium bromide 21 in 85\% (945 mg).

${ }^{1} \mathrm{H}$ NMR (400MHz, CD $\left.3 \mathrm{OD}\right) \delta 8.77(\mathrm{~d}, 2 \mathrm{H}, J=6.4 \mathrm{~Hz}), 8.49(\mathrm{~d}, 2 \mathrm{H}, J=6.0 \mathrm{~Hz}), 8.10(\mathrm{~m}, 4 \mathrm{H})$, $7.41(\mathrm{~d}, 2 \mathrm{H}, J=6.0 \mathrm{~Hz}), 7.16(\mathrm{~d}, 2 \mathrm{H}, J=8.8 \mathrm{~Hz}), 5.53(\mathrm{~s}, 2 \mathrm{H}), 3.97(\mathrm{~s}, 3 \mathrm{H}), 3.44$ (t, 2H, $J=7.8$ $\mathrm{Hz}), 3.24$ (t, 2H, $J=7.8 \mathrm{~Hz}) ;{ }^{13} \mathrm{C}$ NMR (100 MHz, $\left.\mathrm{D}_{2} \mathrm{O}\right) \delta 190.8,165.0,163.0,150.5,148.8$, 145.1, 131.2, 128.0, 126.1, 124.7, 114.7, 55.9, 35.5, 34.1; HRMS (ESI) m/z: calcd. for $\mathrm{C}_{21} \mathrm{H}_{21} \mathrm{~N}_{2} \mathrm{O}_{2}[\mathrm{M}]^{+} 333.1597$, obsd 333.1595 and calcd. for $\mathrm{C}_{21} \mathrm{H}_{22} \mathrm{~N}_{2} \mathrm{O}_{2}[\mathrm{M}+\mathrm{H}]^{2+} 167.0835$, obsd 167.0838 .

\section{2) Indolizine formation}

The pyridinium salt 21 thus obtained $(600 \mathrm{mg}, 1.45 \mathrm{mmol})$ and methyl propiolate (2.2 eq.) were dissolved in anhydrous $\mathrm{CH}_{2} \mathrm{Cl}_{2}(10 \mathrm{~mL})$. $\mathrm{NEt}_{3}$ (1.1 eq.) diluted in $5 \mathrm{~mL}$ of anhydrous $\mathrm{CH}_{2} \mathrm{Cl}_{2}$ was then added dropwise in the reacting mixture. After $5 \mathrm{~h}$ stirring at $\mathrm{rt}$, water was added to the solution. The organic phase was separated and washed 2 more times with water before being dried on $\mathrm{MgSO}_{4}$ and concentrated under reduced pressure. The residue was then purified by flash chromatography on silica gel $\left(\mathrm{CH}_{2} \mathrm{Cl}_{2} / \mathrm{MeOH}\right.$ : $\left.98 / 2\right)$ to obtain indolizine 5 in $61 \%$ yield. ${ }^{1} \mathrm{H}$ NMR $\left(400 \mathrm{MHz}, \mathrm{CDCl}_{3}\right) \delta 9.84(\mathrm{dd}, 1 \mathrm{H}, J=7.2,0.8 \mathrm{~Hz}), 8.56(\mathrm{~d}, 2 \mathrm{H}, J=4.4 \mathrm{~Hz}), 8.21(\mathrm{~d}$, $1 \mathrm{H}, J=0.8 \mathrm{~Hz}), 7.87(\mathrm{~d}, 2 \mathrm{H}, J=8.8 \mathrm{~Hz}), 7.82(\mathrm{~s}, 1 \mathrm{H}), 7.41(\mathrm{~d}, 2 \mathrm{H}, J=6.0 \mathrm{~Hz}), 7.18(\mathrm{~d}, 2 \mathrm{H}, J=4.4$ Hz), 7.04 (d, 2H, J=8.8 Hz), 6.92 (dd, 1H, J=7.2, $2.0 \mathrm{~Hz}), 3.94$ (s, 3H), 3.93 (s, 3H), 3.09 (m, $4 \mathrm{H}) ;{ }^{13} \mathrm{C}$ NMR $\left(100 \mathrm{MHz}, \mathrm{CDCl}_{3}\right) \delta 184.4,164.6,162.6,149.9,149.5,141.3,140.0,132.3$, $131.2,128.9,128.5,123.9,122.5,117.7,116.4,113.7,104.9,55.5,51.2,36.1,35.7$; HRMS (ESI) m/z: calcd. for $\mathrm{C}_{25} \mathrm{H}_{23} \mathrm{~N}_{2} \mathrm{O}_{4}[\mathrm{M}+\mathrm{H}]^{+} 415.1652$, obsd 415.1655 .

\section{Methyl 3-(p-methoxybenzoyl)-7-[2-(1-methylpyridinium-4-yl)ethyl] indolizine-1- carboxylate iodide (7)}

The indolizine 5 (372 mg, $0.9 \mathrm{mmol}$ ) was dissolved in $\mathrm{CH}_{3} \mathrm{CN}$ (8 mL). Iodomethane (1.5 eq.) was added and the solution was stirred at $50^{\circ} \mathrm{C}$ for $4 \mathrm{~h}$. After concentration under vacuum, the brown residue was washed with $\mathrm{CH}_{2} \mathrm{Cl}_{2}$. After drying, the $\mathrm{N}$-alkylpyridinium-indolizine 7 was thus isolated as a brown solid with a quantitative yield.

${ }^{1} \mathrm{H}$ NMR $\left(400 \mathrm{MHz}, \mathrm{CDCl}_{3}\right) \delta 9.70(\mathrm{~d}, 1 \mathrm{H}, J=7.2 \mathrm{~Hz}), 9.04(\mathrm{~d}, 2 \mathrm{H}, J=6.4 \mathrm{~Hz}), 8.05(\mathrm{~s}, 1 \mathrm{H})$, 7.87 (d, 2H, J=6.4 Hz), 7.74 (d, 2H, $J=8.4 \mathrm{~Hz}), 7.69$ (s, 1H), 6.94 (s, 1H), 6.93 (d, 2H, $J=8.8$, $\mathrm{Hz}), 4.57$ (s, 3H), 3.83 (s, 3H), $3.82(\mathrm{~s}, 3 \mathrm{H}), 3.30(\mathrm{t}, 2 \mathrm{H}, J=7.8 \mathrm{~Hz}), 3.13(\mathrm{t}, 2 \mathrm{H}, J=7.8 \mathrm{~Hz}) ;{ }^{13} \mathrm{C}$ NMR (100 MHz, $\left.\mathrm{CDCl}_{3}\right) \delta 184.4,164.6,162.7,161.0,145.1,139.6,139.2,132.1,131.2,129.3$, 128.5, 128.3 122.7, 117.9, 116.3, 113.8, 105.1, 55.5, 51.4, 49.1, 36.2, 35.0; HRMS (ESI) m/z: calcd. for $\mathrm{C}_{26} \mathrm{H}_{25} \mathrm{~N}_{2} \mathrm{O}_{4}[\mathrm{M}]^{+} 429.1809$, obsd 429.1810 . 
Methyl 3-(p-methoxybenzoyl)-7-[2-(1-[(3,5-dimethoxyphenyl)methyl]pyridinium-4yl)ethyl] indolizine-1-carboxylate bromide (8)

The indolizine 5 (125.5 mg, $0.3 \mathrm{mmol}$ ) was dissolved in $\mathrm{CH}_{3} \mathrm{CN}$ (3 mL). 3,5-Dimethoxybenzyl bromide (1.2 eq.) was added and the solution was stirred at $70-80^{\circ} \mathrm{C}$ for $3 \mathrm{~h}$. After concentration under vacuum, the brown residue was washed with $\mathrm{CH}_{2} \mathrm{Cl}_{2}$. After drying, the residue was then purified by flash chromatography on silica gel $\left(\mathrm{CH}_{2} \mathrm{Cl}_{2} / \mathrm{MeOH}\right.$ : $\left.90 / 10\right)$ to obtain the Nalkylpyridinium-indolizine $\mathbf{8}$ as a brown solid in $77 \%$ yield.

${ }^{1} \mathrm{H}$ NMR (400MHz, $\left.\mathrm{CDCl}_{3}\right) \delta 9.73(\mathrm{~d}, 1 \mathrm{H}, J=7.2 \mathrm{~Hz}), 9.30$ (d, 2H, J=6.0 Hz), $8.07(\mathrm{~s}, 1 \mathrm{H})$, 7.80-7.42 (m, 4H), $7.70(\mathrm{~s}, 1 \mathrm{H}), 6.94(\mathrm{~s}, 1 \mathrm{H}), 6.93(\mathrm{~d}, 2 \mathrm{H}, J=8.8, \mathrm{~Hz}), 6.87$ (dd, 1H, J=7.2, 1.6 Hz), 6.73 (d, 2H, J=2.0 Hz), 6.37 (d, 1H, $J=2.0 \mathrm{~Hz}), 6.03$ (s, 2H), $3.83(\mathrm{~s}, 3 \mathrm{H}), 3.82(\mathrm{~s}, 3 \mathrm{H})$, $3.71(\mathrm{~s}, 6 \mathrm{H}), 3.23(\mathrm{t}, 2 \mathrm{H}, J=7.6 \mathrm{~Hz}), 3.09(\mathrm{t}, 2 \mathrm{H}, J=7.6 \mathrm{~Hz}) ;{ }^{13} \mathrm{C} \mathrm{NMR}\left(100 \mathrm{MHz}, \mathrm{CDCl}_{3}\right)$ $\delta 184.5,164.6,162.7,161.7,161.1,144.5,139.7,139.1,134.6,132.2,131.2,129.3,128.4$, 128.0, 122.7, 117.8, 116.0, 113.8, 107.5, 105.1, 102.0, 63.9, 55.9, 55.5, 51.3, 36.0, 34.8; HRMS (ESI) $\mathrm{m} / \mathrm{z}$ : calcd. for $\mathrm{C}_{34} \mathrm{H}_{33} \mathrm{~N}_{2} \mathrm{O}_{6}[\mathrm{M}]^{+}$565.2333, obsd 565.2337.

\section{Methyl 3-(p-methoxybenzoyl)-7-[2-(1-(3-hydroxypropyl)pyridinium-4-yl)ethyl] indolizine-1-carboxylate bromide (9)}

The indolizine 5 (231.5 mg, $0.56 \mathrm{mmol}$ ) was dissolved in $\mathrm{CH}_{3} \mathrm{CN}$ (5 mL). 3-Bromo-1-propanol (3 eq.) was added and the solution was stirred at $70-80^{\circ} \mathrm{C}$ for $20 \mathrm{~h}$. After concentration under vacuum, the residue was then purified by flash chromatography on silica gel $\left(\mathrm{CH}_{2} \mathrm{Cl}_{2} / \mathrm{MeOH}\right.$ : $95 / 5$ to $85 / 15$ ) to obtain the $\mathrm{N}$-alkylpyridinium-indolizine 9 as a yellow solid in 50\% yield.

${ }^{1} \mathrm{H}$ NMR $\left(400 \mathrm{MHz}, \mathrm{CD}_{3} \mathrm{OD}\right) \delta 9.81(\mathrm{~d}, 1 \mathrm{H}, J=7.2 \mathrm{~Hz}), 8.88(\mathrm{~d}, 2 \mathrm{H}, J=6.4 \mathrm{~Hz}), 8.16(\mathrm{~s}, 1 \mathrm{H})$, $8.04(\mathrm{~d}, 2 \mathrm{H}, J=6.8 \mathrm{~Hz}), 7.85$ (d, 2H, $J=8.8 \mathrm{~Hz}), 7.78$ (s, 1H), 7.20 (dd, 1H, $J=7.2,1.6 \mathrm{~Hz})$, $7.13(\mathrm{~d}, 2 \mathrm{H}, J=8.8, \mathrm{~Hz}), 4.72(\mathrm{t}, 2 \mathrm{H}, J=7.0 \mathrm{~Hz}), 3.95(\mathrm{~s}, 3 \mathrm{H}), 3.91(\mathrm{~s}, 3 \mathrm{H}), 3.63(\mathrm{t}, 2 \mathrm{H}, J=5.6$ $\mathrm{Hz}), 3.46(\mathrm{t}, 2 \mathrm{H}, J=7.4 \mathrm{~Hz}), 3.32(\mathrm{t}, 2 \mathrm{H}, J=7.2 \mathrm{~Hz}), 2.21(\mathrm{~m}, 2 \mathrm{H}) ;{ }^{13} \mathrm{C} \mathrm{NMR}(100 \mathrm{MHz}$, DMSO-d 6$) \delta 183.3,163.5,162.2,160.8,144.3,141.4,139.0,134.6,132.2,131.5,130.9$, 128.4, 127.7, 127.3, 121.9, 117.2, 117.0, 113.9, 104.0, 57.9, 57.1, 55.5, 51.1, 34.9, 34.2, 33.2; HRMS (ESI) m/z: calcd. for $\mathrm{C}_{28} \mathrm{H}_{29} \mathrm{~N}_{2} \mathrm{O}_{5}[\mathrm{M}]^{+} 473.2071$, obsd 473.2074 and calcd. for $\mathrm{C}_{28} \mathrm{H}_{30} \mathrm{~N}_{2} \mathrm{O}_{5}[\mathrm{M}+\mathrm{H}]^{2+}$ 237.1072, obsd 237.1071.

\section{Dimethyl 7-[2-(4-pyridinyl)ethyl] indolizine-1,3-dicarboxylate (6)}

This compound was prepared in two steps from 1,2-Bis(4-pyridyl)ethane:

1) N-Alkylation

1,2-Bis(4-pyridyl)ethane (504 mg, $2.74 \mathrm{mmol}$ ) was dissolved in $\mathrm{CH}_{3} \mathrm{CN}$ (15 mL). Methyl bromoacetate $\left(0.9\right.$ eq.) was added and the solution was stirred at $70-80^{\circ} \mathrm{C}$ for $3 \mathrm{~h}$. The white precipitate (dialkylated product) was removed by filtration. After concentration under vacuum, water was added then the aqueous solution was washed 4 times with AcOEt to remove the residual 1,2-bis(4-pyridyl)ethane. After aqueous phase concentration under vacuum, the residue was washed twice with $\mathrm{CH}_{3} \mathrm{CN}$. The organic solution was concentrated in vacuo to give an orange oil composed of a 4/1 mixture of 1-(2-Methoxy-2-oxoethyl)-4-[2-(4pyridinyl)ethyl]pyridinium bromide $\mathbf{2 2}$ and 4,4'-(1,2-ethanediyl)bis[1-(2-methoxy-2oxoethyl)pyridinium] dibromide $\mathbf{2 3}$ in $30 \%$ yield. The mixture was directly used for the next step without purification.

2) Indolizine formation 
The 23/23 pyridinium mixture $(145 \mathrm{mg}, 0.43 \mathrm{mmol})$ and methyl propiolate $(2.1 \mathrm{eq}$.) were dissolved in anh. $\mathrm{CH}_{2} \mathrm{Cl}_{2}(4 \mathrm{~mL})$. $\mathrm{NEt}_{3}$ (1.2 eq.) diluted in $1 \mathrm{~mL}$ of anh. $\mathrm{CH}_{2} \mathrm{Cl}_{2}$ was then added dropwise in the reacting mixture. After $2 \mathrm{~h}$ stirring at rt. water was added to the solution. The organic phase was separated and washed 2 more times with water and brine before being dried on $\mathrm{MgSO}_{4}$ and concentrated under reduced pressure. The residue was then purified by flash chromatography on silica gel $\left(\mathrm{CH}_{2} \mathrm{Cl}_{2} / \mathrm{MeOH}\right.$ : $\left.98 / 2\right)$ to obtain indolizine $\mathbf{6}$ as an amorphous orange solid in $40 \%$ yield.

${ }^{1} \mathrm{H}$ NMR (400MHz, $\left.\mathrm{CDCl}_{3}\right) \delta 9.46(\mathrm{dd}, 1 \mathrm{H}, J=7.2,0.8 \mathrm{~Hz}), 8.56$ (dd, 2H, $\left.J=4.4,1.6 \mathrm{~Hz}\right), 8.19$ (d, 1H, J=0.8 Hz), 7.99 (s, 1H), 7.17 (dd, 2H, J=4.4, 1.6 Hz), 6.84 (dd, 1H, J=7.2, $2.0 \mathrm{~Hz}$ ), 3.96 (s, 3H), 3.95 (s, 3H), 3.07 (m, 4H); $\left.{ }^{13} \mathrm{C} \mathrm{NMR} \mathrm{(100} \mathrm{MHz,} \mathrm{CDCl}_{3}\right) \delta 164.7,161.6,150.0$, 149.5, 139.5, 139.4, $127.8124 .5,123.8,117.9,115.9,114.2,104.2,51.4,51.2,36.0,35.8$; HRMS (ESI) m/z: calcd. for $\mathrm{C}_{19} \mathrm{H}_{19} \mathrm{~N}_{2} \mathrm{O}_{4}[\mathrm{M}+\mathrm{H}]^{+} 339.1339$, obsd 339.1338.

\section{Dimethyl 7-[2-(1-methylpyridinium-4-yl)ethyl]indolizine-1,3-dicarboxylate iodide (10)}

The indolizine 6 (42 mg, $0.12 \mathrm{mmol}$ ) was dissolved in $\mathrm{CH}_{3} \mathrm{CN}(2 \mathrm{~mL})$. Iodomethane (1.5 eq.) was added and the solution was stirred at $50^{\circ} \mathrm{C}$ for $2 \mathrm{~h}$ before adding another portion of iodomethane (1.5 eq.). After $2 \mathrm{~h}$ more stirring, the solution was concentrated under vacuum. The residue was then purified by flash chromatography on silica gel $\left(\mathrm{CH}_{2} \mathrm{Cl}_{2} / \mathrm{MeOH}: 96 / 4\right.$ to $90 / 10$ ) to obtain the $\mathrm{N}$-alkylpyridinium-indolizine $\mathbf{1 0}$ was thus isolated as a yellow solid in $85 \%$ yield.

${ }^{1} \mathrm{H}$ NMR $\left(400 \mathrm{MHz}, \mathrm{CDCl}_{3}\right) \delta 9.49(\mathrm{~d}, 1 \mathrm{H}, J=6.8 \mathrm{~Hz}), 9.10(\mathrm{~d}, 2 \mathrm{H}, J=5.6 \mathrm{~Hz}), 8.12(\mathrm{~s}, 1 \mathrm{H})$, $7.99(\mathrm{~s}, 1 \mathrm{H}), 7.93(\mathrm{~d}, 2 \mathrm{H}, J=5.6 \mathrm{~Hz}), 6.92(\mathrm{~d}, 1 \mathrm{H}, J=6.8 \mathrm{~Hz}), 4.67(\mathrm{~s}, 3 \mathrm{H}), 3.96(\mathrm{~s}, 3 \mathrm{H}), 3.95(\mathrm{~s}$, $3 \mathrm{H}), 3.39(\mathrm{t}, 2 \mathrm{H}, J=7.6 \mathrm{~Hz}), 3.22(\mathrm{t}, 2 \mathrm{H}, J=7.8 \mathrm{~Hz}) ;{ }^{13} \mathrm{C} \mathrm{NMR}\left(100 \mathrm{MHz}, \mathrm{CDCl}_{3}\right) \delta 164.6$, 161.4, 161.1, 145.1, 138.9, 137.6, 128.3 128.0, 124.1, 117.9, 115.7, 114.5, 104.4, 51.5, 51.3, 49.0, 36.2, 34.9; HRMS (ESI) m/z: calcd. for $\mathrm{C}_{20} \mathrm{H}_{21} \mathrm{~N}_{2} \mathrm{O}_{4}[\mathrm{M}]^{+} 353.1496$, obsd 353.1497.

\section{Ind-PyC3 series}

Methyl 3-(p-methoxybenzoyl)-7-[3-(4-pyridinyl)propyl] indolizine-1-carboxylate (11)

This compound was prepared in two steps from 1,3-Bis(4-pyridyl)propane

1) N-Alkylation

1,3-Bis(4-pyridyl)propane (676 mg, $3.4 \mathrm{mmol}$ ) was dissolved in $\mathrm{CH}_{3} \mathrm{CN}$ (8 mL). 2-Bromo-pmethoxyacetophenone ( 1 eq.) was added and the solution was stirred at $70-80^{\circ} \mathrm{C}$ for $2 \mathrm{~h}$. The white precipitate was filtrated and then purified by flash chromatography on silica gel $\left(\mathrm{CH}_{2} \mathrm{Cl}_{2} / \mathrm{MeOH}: \quad 90 / 10\right)$. The 1-(2-(4-Methoxyphenyl-2-oxoethyl)-4-[3-(4pyridinyl)propyl]pyridinium bromide $\mathbf{2 4}$ was thus isolated as a white solid in $41 \%$ yield (600 $\mathrm{mg})$.

${ }^{1} \mathrm{H}$ NMR (400MHz, CD $\left.3 \mathrm{OD}\right) \delta 8.76(\mathrm{~d}, 2 \mathrm{H}, J=6.8 \mathrm{~Hz}), 8.49$ (dd, 2H, $\left.J=4.8,1.6 \mathrm{~Hz}\right), 8.13-8.08$ (m, 4H), $7.40(\mathrm{dd}, 2 \mathrm{H}, J=4.8,1.6 \mathrm{~Hz}), 7.17(\mathrm{dd}, 2 \mathrm{H}, J=6.8,2.0 \mathrm{~Hz}), 3.97$ (s, 3H), 3.11 (t, 2H, $J=7.8 \mathrm{~Hz}), 2.87(\mathrm{t}, 2 \mathrm{H}, J=7.8 \mathrm{~Hz}), 2.21(\mathrm{~m}, 2 \mathrm{H}) ;{ }^{13} \mathrm{C} \mathrm{NMR}\left(100 \mathrm{MHz}, \mathrm{CD}_{3} \mathrm{OD}\right) \delta 188.2,165.2$, 163.7, 152.1, 148.6, 145.4, 130.5, 127.4, 127.3, 126.3, 124.3, 114.1, 54.9, 34.7, 34.0, 29.6; HRMS (ESI) $\mathrm{m} / \mathrm{z}$ : calcd. for $\mathrm{C}_{22} \mathrm{H}_{23} \mathrm{~N}_{2} \mathrm{O}_{2}[\mathrm{M}]^{+} 347.1754$, obsd 347.1754 and calcd. for $\mathrm{C}_{22} \mathrm{H}_{24} \mathrm{~N}_{2} \mathrm{O}_{2}[\mathrm{M}+\mathrm{H}]^{2+}$ 174.0913, obsd 174.0917.

2) Indolizine formation 
The pyridinium salt $24(540 \mathrm{mg}, 1.26 \mathrm{mmol})$ and methyl propiolate (2.2 eq.) were dissolved in anh. $\mathrm{CH}_{2} \mathrm{Cl}_{2}(10 \mathrm{~mL})$. $\mathrm{NEt}_{3}$ (1.2 eq.) diluted in $5 \mathrm{~mL}$ of anh. $\mathrm{CH}_{2} \mathrm{Cl}_{2}$ was then added dropwise in the reacting mixture. After $2 \mathrm{~h}$ stirring at $\mathrm{rt}$, water was added to the solution. The organic phase was separated and washed 2 more times with water and brine before being dried on $\mathrm{MgSO}_{4}$ and concentrated under reduced pressure. The residue was then purified by flash chromatography on silica gel $\left(\mathrm{CH}_{2} \mathrm{Cl}_{2} / \mathrm{MeOH}\right.$ : $\left.98 / 2\right)$ to obtain indolizine 11 in $68 \%$ yield. ${ }^{1} \mathrm{H}$ NMR $\left(400 \mathrm{MHz}, \mathrm{CDCl}_{3}\right) \delta 9.74(\mathrm{~d}, 1 \mathrm{H}, J=7.2 \mathrm{~Hz}), 8.44(\mathrm{~d}, 2 \mathrm{H}, J=5.6 \mathrm{~Hz}), 8.10(\mathrm{~s}, 1 \mathrm{H})$, $7.75(\mathrm{~d}, 2 \mathrm{H}, J=8.8 \mathrm{~Hz}), 7.71(\mathrm{~s}, 1 \mathrm{H}), 7.06(\mathrm{~d}, 2 \mathrm{H}, J=6.0 \mathrm{~Hz}), 6.93(\mathrm{~d}, 2 \mathrm{H}, J=8.8 \mathrm{~Hz}), 6.83$ (dd, $1 \mathrm{H}, J=7.2,1.6 \mathrm{~Hz}), 3.82(\mathrm{~s}, 6 \mathrm{H}), 2.71$ (t, 2H, $J=7.6 \mathrm{~Hz}), 2.62$ (t, 2H, $J=7.6 \mathrm{~Hz}), 1.99$ (m, 4H); ${ }^{13} \mathrm{C}$ NMR $\left(100 \mathrm{MHz}, \mathrm{CDCl}_{3}\right) \delta 184.4,164.7,162.6,150.5,149.8,142.4,140.2,132.4,131.2$, 128.9, 128.6, 123.9, 122.5, 117.7, 116.5, 113.7, 104.7, 55.5, 51.2, 35.0, 34.6, 30.7; HRMS (ESI) $\mathrm{m} / \mathrm{z}$ : calcd. for $\mathrm{C}_{26} \mathrm{H}_{25} \mathrm{~N}_{2} \mathrm{O}_{4}[\mathrm{M}+\mathrm{H}]^{+} 429.1809$, obsd 429.1810 .

\section{Methyl 3-(p-methoxybenzoyl)-7-[3-(1-methylpyridinium-4-yl)propyl] indolizine-1- carboxylate iodide (13)}

The indolizine 11 (102 mg, $0.24 \mathrm{mmol}$ ) was dissolved in $\mathrm{CH}_{3} \mathrm{CN}$ (4 mL). Iodomethane (1.5 eq.) was added and the solution was stirred at $50^{\circ} \mathrm{C}$ for $4 \mathrm{~h}$. After concentration under vacuum, the brown residue was washed with $\mathrm{CH}_{2} \mathrm{Cl}_{2}$. After drying, the $\mathrm{N}$-alkylpyridinium-indolizine $\mathbf{1 3}$ was thus isolated as an orange solid with a quantitative yield.

${ }^{1} \mathrm{H} \mathrm{NMR}\left(400 \mathrm{MHz}, \mathrm{CDCl}_{3}\right) \delta 9.71(\mathrm{~d}, 1 \mathrm{H}, J=7.2 \mathrm{~Hz}), 9.04$ (d, 2H, $\left.J=6.0 \mathrm{~Hz}\right), 8.08(\mathrm{~s}, 1 \mathrm{H})$, $7.83(\mathrm{~d}, 2 \mathrm{H}, J=6.4 \mathrm{~Hz}), 7.75$ (d, 2H, $J=8.4 \mathrm{~Hz}), 7.70$ (s, 1H), 6.93 (d, 2H, J=8.4, Hz), 6.90 (dd, $1 \mathrm{H}, J=7.2,1.6 \mathrm{~Hz}), 4.57$ (s, 3H), $3.83(\mathrm{~s}, 3 \mathrm{H}), 3.82(\mathrm{~s}, 3 \mathrm{H}), 2.91(\mathrm{t}, 2 \mathrm{H}, J=7.6 \mathrm{~Hz}), 2.79(\mathrm{t}, 2 \mathrm{H}$, $J=7.6 \mathrm{~Hz}), 2.08(\mathrm{~m}, 2 \mathrm{H}) ;{ }^{13} \mathrm{C} \mathrm{NMR}\left(100 \mathrm{MHz}, \mathrm{CDCl}_{3}\right) \delta 184.4,164.6,162.6,162.3,145.0$, $141.1,139.9,132.2,131.2,129.1,128.5,128.1,122.6,117.8,116.4,113.8,104.9,55.5,51.3$, 49.0, 35.1, 34.7, 30.0; HRMS (ESI) m/z: calcd. for $\mathrm{C}_{27} \mathrm{H}_{27} \mathrm{~N}_{2} \mathrm{O}_{4}[\mathrm{M}]^{+} 443.1965$, obsd 443.1966 .

\section{Methyl 3-(p-methoxybenzoyl)-7-[3-(1-[(3,5-dimethoxyphenyl)methyl]pyridinium-4- yl)propyl] indolizine-1-carboxylate bromide (14)}

The indolizine 11 (193 mg, $0.45 \mathrm{mmol}$ ) was dissolved in $\mathrm{CH}_{3} \mathrm{CN}$ (4 mL). 3,5-Dimethoxybenzyl bromide (1.2 eq.) was added and the solution was stirred at $70-80^{\circ} \mathrm{C}$ for $3 \mathrm{~h}$. After concentration under vacuum, the brown residue was washed with $\mathrm{CH}_{2} \mathrm{Cl}_{2}$. After drying, the $\mathrm{N}$ alkylpyridinium-indolizine $\mathbf{1 4}$ was thus isolated as a brown solid with a quantitative yield.

${ }^{1} \mathrm{H}$ NMR $\left(400 \mathrm{MHz}, \mathrm{CDCl}_{3}\right) \delta 9.73(\mathrm{~d}, 1 \mathrm{H}, J=7.2 \mathrm{~Hz}), 9.31$ (d, 2H, J=6.4 Hz), 8.09 (s, 1H), 7.77-7.71 (m, 5H), $6.94(\mathrm{dd}, 2 \mathrm{H}, J=6.8,2.0 \mathrm{~Hz}), 6.85(\mathrm{~d}, 1 \mathrm{H}, J=7.2 \mathrm{~Hz}), 6.76(\mathrm{~d}, 2 \mathrm{H}, J=2.0$ $\mathrm{Hz}), 6.36(\mathrm{dd}, 1 \mathrm{H}, J=2.0 \mathrm{~Hz}), 6.04(\mathrm{~s}, 2 \mathrm{H}), 3.83(\mathrm{~s}, 3 \mathrm{H}), 3.82(\mathrm{~s}, 3 \mathrm{H}), 3.71(\mathrm{~s}, 6 \mathrm{H}), 2.85(\mathrm{t}, 2 \mathrm{H}$, $J=7.6 \mathrm{~Hz}), 2.77(\mathrm{t}, 2 \mathrm{H}, J=7.6 \mathrm{~Hz}), 2.04(\mathrm{~m}, 2 \mathrm{H}) ;{ }^{13} \mathrm{C} \mathrm{NMR}\left(100 \mathrm{MHz}, \mathrm{CDCl}_{3}\right) \delta 184.4,164.6$, 162.6162 .2 , 161.7, 144.4, 141.0, 139.9, 134.7, 132.3, 131.2, 129.1, 128.5, 127.8, 122.6, 117.7, 116.3, 113.8, 107.5, 104.9, 102.0, 63.8, 55.9, 55.5, 51.3, 35.1, 34.8, 29.8; HRMS (ESI) m/z: calcd. for $\mathrm{C}_{35} \mathrm{H}_{35} \mathrm{~N}_{2} \mathrm{O}_{6}[\mathrm{M}]^{+} 579.2490$, obsd 579.2495 and calcd. for $\mathrm{C}_{35} \mathrm{H}_{36} \mathrm{~N}_{2} \mathrm{O} 6[\mathrm{M}+\mathrm{H}]^{2+}$ 290.1281, obsd 290.1279.

\section{Dimethyl 7-[3-(4-pyridinyl)propyl] indolizine-1,3-dicarboxylate (12)}

This compound was prepared in two steps from 1,3-Bis(4-pyridyl)propane

1) N-Alkylation 
1,3-Bis(4-pyridyl)propane (502 $\mathrm{mg}, 2.53 \mathrm{mmol}$ ) was dissolved in $\mathrm{CH}_{3} \mathrm{CN}$ (5 mL). Methyl bromoacetate $\left(0.9\right.$ eq.) was added and the solution was stirred at $70-80^{\circ} \mathrm{C}$ for $3 \mathrm{~h}$. After concentration under vacuum, water was added then the aqueous solution was washed 4 times with $\mathrm{CH}_{2} \mathrm{Cl}_{2}$ to remove the residual 1,3-Bis(4-pyridyl)propane. After aqueous phase concentration under vacuum, the residue was washed with cold $\mathrm{CH}_{3} \mathrm{CN}$. The organic solution was concentrated to give brown oil composed of a 10/1 mixture of 1-(2-methoxy-2-oxoethyl)4-[3-(4-pyridinyl)propyl]pyridinium bromide 25 and 4,4'-(1,3-propanediyl)bis[1-(2-methoxy2-oxoethyl) pyridinium] dibromide 26 in 55\% yield. The mixture was directly used in the next step.

2) Indolizine formation

The $\mathbf{2 5} / \mathbf{2 6}$ pyridinium mixture $(217 \mathrm{mg}, 0.62 \mathrm{mmol}$ ) and methyl propiolate (2.1 eq.) were dissolved in anh. $\mathrm{CH}_{2} \mathrm{Cl}_{2}(5 \mathrm{~mL})$. $\mathrm{NEt}_{3}$ (1.2 eq.) diluted in $2 \mathrm{~mL}$ of anh. $\mathrm{CH}_{2} \mathrm{Cl}_{2}$ was then added dropwise in the reacting mixture. After $4 \mathrm{~h}$ stirring at $\mathrm{rt}$ water was added to the solution. The organic phase was separated and washed 2 more times with water and brine before being dried on $\mathrm{MgSO}_{4}$ and concentrated under reduced pressure. The residue was then purified by flash chromatography on silica gel $\left(\mathrm{CH}_{2} \mathrm{Cl}_{2} / \mathrm{MeOH}\right.$ : $\left.98 / 2\right)$ to obtain indolizine 12 as an amorphous orange solid in $55 \%$.

${ }^{1} \mathrm{H}$ NMR (400MHz, $\left.\mathrm{CDCl}_{3}\right) \delta 9.43(\mathrm{~d}, 1 \mathrm{H}, J=7.2 \mathrm{~Hz}), 8.52(\mathrm{~d}, 2 \mathrm{H}, J=4.4 \mathrm{~Hz}), 8.16(\mathrm{~s}, 1 \mathrm{H})$, 7.96 (s, 1H), 7.15 (d, 2H, J=4.4 Hz), 6.85 (d, 1H, $J=7.2 \mathrm{~Hz}), 3.93(\mathrm{~s}, 6 \mathrm{H}), 2.77$ (t, 2H, $J=7.6$ $\mathrm{Hz}), 2.71(\mathrm{t}, 2 \mathrm{H}, J=7.6 \mathrm{~Hz}), 2.07(\mathrm{~m}, 2 \mathrm{H}) ;{ }^{13} \mathrm{C} \mathrm{NMR}\left(100 \mathrm{MHz}, \mathrm{CDCl}_{3}\right) \delta 164.7,161.5,150.6$, $149.7,140.5,139.5,127.7124 .5,124.1,123.9,117.7,115.9,114.1,104.0,51.9,51.3,34.9$, 34.6, 30.7; HRMS (ESI) m/z: calcd. for $\mathrm{C}_{12} \mathrm{H}_{21} \mathrm{~N}_{2} \mathrm{O}_{4}[\mathrm{M}+\mathrm{H}]^{+} 353.1496$, obsd 353.1495.

Dimethyl 7-[3-(1-methylpyridinium-4-yl)propyl]indolizine-1,3-dicarboxylate iodide (15) The indolizine $12(50 \mathrm{mg}, 0.14 \mathrm{mmol})$ was dissolved in $\mathrm{CH}_{3} \mathrm{CN}$ (2 mL). Iodomethane (3 eq.) was added and the solution was stirred at $60^{\circ} \mathrm{C}$ for $3 \mathrm{~h}$. After concentration under vacuum, the brown residue was washed with $\mathrm{CH}_{2} \mathrm{Cl}_{2}$ and $\mathrm{Et}_{2} \mathrm{O}$. After drying, the N-alkylpyridiniumindolizine 15 was thus isolated as a brownish solid (71\%).

${ }^{1} \mathrm{H}$ NMR (400MHz, $\left.\mathrm{CDCl}_{3}\right) \delta 9.46(\mathrm{~d}, 1 \mathrm{H}, J=7.2 \mathrm{~Hz}), 9.15$ (d, 2H, J=6.4 Hz), $8.15(\mathrm{~s}, 1 \mathrm{H})$, $7.98(\mathrm{~s}, 1 \mathrm{H}), 7.93$ (d, 2H, J=6.4 Hz), 6.93 (d, 1H, $J=7.2 \mathrm{~Hz}), 4.68(\mathrm{~s}, 3 \mathrm{H}), 3.95$ (s, 6H), 3.02 (t, $2 \mathrm{H}, J=7.6 \mathrm{~Hz}), 2.87$ (t, $2 \mathrm{H}, J=7.6 \mathrm{~Hz}), 2.18(\mathrm{~m}, 2 \mathrm{H}) ;{ }^{13} \mathrm{C} \mathrm{NMR}\left(100 \mathrm{MHz}, \mathrm{CDCl}_{3}\right) \delta 164.7$, $162.3,161.5,145.0,139.3,128.0127 .9,124.5,117.9,115.9,114.3,104.2,51.5,51.3,49.0$, 35.1, 34.6, 30.0; HRMS (ESI) m/z: calcd. for $\mathrm{C}_{21} \mathrm{H}_{23} \mathrm{~N}_{2} \mathrm{O}_{4}[\mathrm{M}]^{+}$367.1652, obsd 367.1651.

\section{Dimethyl 7-[3-(1-[(3,5-dimethoxyphenyl)methyl]pyridinium-4-yl)propyl] indolizine1,3- dicarboxylate bromide (16)}

The indolizine 12 (58 mg, $0.14 \mathrm{mmol}$ ) was dissolved in $\mathrm{CH}_{3} \mathrm{CN}$ (2 mL). 3,5-Dimethoxybenzyl bromide (1.1 eq.) was added and the solution was stirred at $70^{\circ} \mathrm{C}$ for $3 \mathrm{~h}$. After concentration under vacuum, the brown residue was washed with $\mathrm{CH}_{2} \mathrm{Cl}_{2}$ and $\mathrm{Et}_{2} \mathrm{O}$. After drying, the Nalkylpyridinium-indolizine $\mathbf{1 6}$ was thus isolated as a brownish solid in $90 \%$ yield.

${ }^{1} \mathrm{H}$ NMR (400MHz, $\left.\mathrm{CDCl}_{3}\right) \delta 9.47(\mathrm{~d}, 1 \mathrm{H}, J=7.2 \mathrm{~Hz}), 9.43$ (d, 2H, J=5.6 Hz), $8.16(\mathrm{~s}, 1 \mathrm{H})$, $7.98(\mathrm{~s}, 1 \mathrm{H}), 7.83(\mathrm{~d}, 2 \mathrm{H}, J=5.6 \mathrm{~Hz}), 6.88(\mathrm{~m}, 3 \mathrm{H}), 6.48(\mathrm{~s}, 1 \mathrm{H}), 6.15(\mathrm{~s}, 2 \mathrm{H}), 3.96(\mathrm{~s}, 6 \mathrm{H}), 3.83$ $(\mathrm{s}, 6 \mathrm{H}), 2.95(\mathrm{t}, 2 \mathrm{H}, J=7.6 \mathrm{~Hz}), 2.85(\mathrm{t}, 2 \mathrm{H}, J=7.6 \mathrm{~Hz}), 2.13(\mathrm{~m}, 2 \mathrm{H}) ;{ }^{13} \mathrm{C}$ NMR $(100 \mathrm{MHz}$, $\left.\mathrm{CDCl}_{3}\right) \delta 164.7,162.3,161.7,161.5,144.4,139.3,139.2,134.6,128.0127 .8,124.5,117.8$, 
115.7, 114.4, 107.5, 107.0, 104.2, 102.0, 63.7, 55.9, 55.4, 51.4, 51.2, 35.1, 34.7, 29.8; HRMS (ESI) m/z: calcd. for $\mathrm{C}_{29} \mathrm{H}_{31} \mathrm{~N}_{2} \mathrm{O}_{6}[\mathrm{M}]^{+}$503.2177, obsd 503.2179.

\begin{abstract}
Bis-pyridinium salts
1-Methyl-4-[2-[1-(2-methoxy-2-oxoethyl)pyridinium-4-yl]ethyl]pyridinium bromide and iodide (18)

1-Methyl-4-[2-(4-pyridinyl)ethyl]-pyridinium iodide ${ }^{50}$ (315 $\mathrm{mg}, 0.97 \mathrm{mmol}$ ) was dissolved in $\mathrm{CH}_{3} \mathrm{CN}\left(7 \mathrm{~mL}\right.$ ). Methyl bromoacetate (3 eq.) was added and the solution was stirred at $70-80^{\circ} \mathrm{C}$ for $20 \mathrm{~h}$. After concentration under vacuum, the residue was washed 3 times with $\mathrm{CH}_{2} \mathrm{Cl}_{2}$. After drying, the bi-pyridinium 18 was thus isolated as a brown solid in 20\% yield (246 $\mathrm{mg}$ ).

${ }^{1} \mathrm{H}$ NMR $\left(400 \mathrm{MHz}, \mathrm{CD}_{3} \mathrm{OD}\right) \delta 8.89(\mathrm{~d}, 2 \mathrm{H}, J=6.8 \mathrm{~Hz}), 8.84(\mathrm{~d}, 2 \mathrm{H}, J=6.8 \mathrm{~Hz}), 8.17(\mathrm{~d}, 2 \mathrm{H}$, $J=6.8 \mathrm{~Hz}), 8.08$ (d, 2H, $J=6.8 \mathrm{~Hz}), 5.59$ (s, 2H), 4.40 (s, 3H), 3.89 (s, 3H), $3.49(\mathrm{~m}, 4 \mathrm{H}) ;{ }^{13} \mathrm{C}$ NMR (100 MHz, $\left.\mathrm{D}_{2} 0\right) \delta 168.0,162.3,160.0,145.4,144.8,128.1,127.9,125.8,60.3,54.0,47.6$, 34.4, 34.1; HRMS (ESI) m/z: calcd. for $\mathrm{C}_{16} \mathrm{H}_{19} \mathrm{~N}_{2} \mathrm{O}_{2}[\mathrm{M}-\mathrm{H}]^{+} 271.1441$, obsd 271.1440 and calcd. for $\mathrm{C}_{16} \mathrm{H}_{20} \mathrm{~N}_{2} \mathrm{O}_{2}[\mathrm{M}]^{2+}$ 136.0767, obsd 136.0759.
\end{abstract}

\title{
1-[2-(4-Methoxyphenyl)-2-oxoethyl]-4-[3-(1-methylpyridinium-4-yl)propyl]-pyridinium iodide and bromide (19)
}

1-Methyl-4-[3-(4-pyridinyl)propyl]-pyridinium iodide ${ }^{51}(238 \mathrm{mg}, 0.7 \mathrm{mmol})$ was dissolved in $\mathrm{CH}_{3} \mathrm{CN}$ ( $8 \mathrm{~mL}$ ). 2-Bromo- $p$-methoxyacetophenone (3 eq.) was added and the solution was stirred at $70-80^{\circ} \mathrm{C}$ for $20 \mathrm{~h}$. After concentration under vacuum, the residue was washed 3 times with $\mathrm{CH}_{2} \mathrm{Cl}_{2}$. After drying, the bi-pyridinium 19 was thus isolated as a brown solid in $93 \%$ yield.

${ }^{1} \mathrm{H}$ NMR $\left(400 \mathrm{MHz}, \mathrm{CD}_{3} \mathrm{OD}\right) \delta 8.81(\mathrm{~d}, 2 \mathrm{H}, J=6.4 \mathrm{~Hz}), 8.78(\mathrm{~d}, 2 \mathrm{H}, J=6.8 \mathrm{~Hz}), 8.13(\mathrm{~d}, 2 \mathrm{H}$, $J=6.4 \mathrm{~Hz}), 8.11$ (d, 2H, $J=9.2 \mathrm{~Hz}), 8.04$ (d, 2H, $J=6.4 \mathrm{~Hz}), 7.15$ (d, 2H, $J=8.8 \mathrm{~Hz}), 4.40$ (s, $3 \mathrm{H}), 3.95(\mathrm{~s}, 3 \mathrm{H}), 3.15(\mathrm{~m}, 4 \mathrm{H}), 2.30(\mathrm{~m}, 2 \mathrm{H}) ;{ }^{13} \mathrm{C} \mathrm{NMR}\left(100 \mathrm{MHz}, \mathrm{D}_{2} \mathrm{O}\right) \delta 190.8,163.8,164.4$, 162.1 145.3, 144.6, 131.3, 128.0, 126.2, 114.8, 56.1, 47.7, 34.8, 34.5, 28.5; HRMS (ESI) m/z: calcd. for $\mathrm{C}_{23} \mathrm{H}_{25} \mathrm{~N}_{2} \mathrm{O}_{2}[\mathrm{M}-\mathrm{H}]^{+} 361.1911$, obsd 361.1912 and calcd. for $\mathrm{C}_{23} \mathrm{H}_{26} \mathrm{~N}_{2} \mathrm{O}_{2}[\mathrm{M}]^{2+}$ 181.0992, obsd 181.0996.

\section{1-Methyl-4-[3-[1-(2-methoxy-2-oxoethyl)pyridinium-4-yl]propyl]pyridinium bromide and iodide (20)}

1-Methyl-4-[2-(4-pyridinyl)propyl]-pyridinium iodide ${ }^{51}(216 \mathrm{mg}, 0.63 \mathrm{mmol})$ was dissolved in $\mathrm{CH}_{3} \mathrm{CN}\left(5 \mathrm{~mL}\right.$ ). Methyl bromoacetate (2 eq.) was added and the solution was stirred at $70-80^{\circ} \mathrm{C}$ for $5 \mathrm{~h}$. After concentration under vacuum, the residue was washed 3 times with $\mathrm{CH}_{2} \mathrm{Cl}_{2}$. After drying, the bi-pyridinium 20 was thus isolated as a brown solid in $80 \%$ yield $(246 \mathrm{mg}$ ).

${ }^{1} \mathrm{H}$ NMR (400MHz, CD $\left.3 \mathrm{OD}\right) \delta 8.89$ (d, 2H, $J=6.8 \mathrm{~Hz}$ ), 8.83 (d, 2H, $\left.J=6.8 \mathrm{~Hz}\right), 8.15$ (d, 2H, $J=6.8 \mathrm{~Hz}), 8.06(\mathrm{~d}, 2 \mathrm{H}, J=6.8 \mathrm{~Hz}), 5.61$ (s, 2H), 4.42 (s, 3H), 3.91 (s, 3H), 3.15 (m, 4H), 2.29 $(\mathrm{m}, 2 \mathrm{H}) ;{ }^{13} \mathrm{C}$ NMR $\left(100 \mathrm{MHz}, \mathrm{D}_{2} \mathrm{O}\right) \delta 168.2,164.4,162.1,145.2,144.6,128.8,128.0,125.2$, 60.4, 54.2, 47.7, 34.8, 34.5, 28.5; HRMS (ESI) m/z: calcd. for $\mathrm{C}_{17} \mathrm{H}_{21} \mathrm{~N}_{2} \mathrm{O}_{2}[\mathrm{M}-\mathrm{H}]^{+}$285.1598, obsd 285.1597 and calcd. for $\mathrm{C}_{17} \mathrm{H}_{22} \mathrm{~N}_{2} \mathrm{O}_{2}[\mathrm{M}]^{2+} 143.0835$, obsd 143.0838.

\section{Antioxidant activity: DPPH assay}


The DPPH free radical has a maximum absorption at $517 \mathrm{~nm}$, which gives a purple color. In a 96-well plate, $100 \mu \mathrm{L}$ of a $100 \mu \mathrm{g} / \mathrm{mL}$ DPPH methanolic solution were added to $100 \mu \mathrm{L}$ samples with a concentration ranging from 50 to $1500 \mu \mathrm{g} / \mathrm{mL}$ in methanol. The resulting solutions were then homogenized and left in the dark at room temperature for 35 minutes. The absorbance values at $517 \mathrm{~nm}$ were recorded after this time period. The blank sample used was a 1:1 mixture of methanol and DPPH solution. A $48 \mu \mathrm{g} / \mathrm{mL}$ solution of rutin was used as a reference standard. The DPPH inhibition percentage, which relates to the antioxidant activity of rutin and the compounds, was calculated using the following formula: $\%$ inhibition $=\left(A_{\text {blank }}-A_{\text {sample }}\right) / A_{\text {blank }}$ *100. The assay is performed in triplicates. The initial solutions of samples were prepared by dilution of $20 \mathrm{mM}$ stock DMSO solutions with $\mathrm{MeOH}$ to reach the concentration of $3 \mathrm{mg} / \mathrm{mL}$. For all tested compounds, the highest concentration in well is $0.75 \mathrm{mg} / \mathrm{mL}$.

\section{Cholinesterase inhibition assays}

Acetylcholinesterase ((E.C. 3.1.1.7) from Electrophorus electricus (eeAChE), Type V-S, (Sigma C2888) $\geq 1000 \mathrm{U} / \mathrm{mg}$ protein; Butyrylcholinesterase (E.C. 3.1.1.8) from equine serum (eqBChE) (Sigma ref C1057), $\geq 900 \mathrm{U} / \mathrm{mg}$ protein; Human acetylcholinesterase, recombinant,

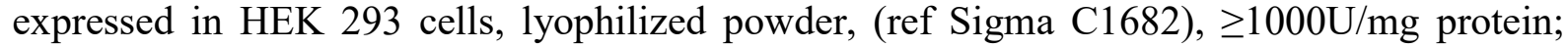
Human butyrylcholinesterase (hBChE) from human serum ('ref B4186), 4U/vial; 5,5'dithiobis-(2- nitrobenzoic acid) (Ellman's reagent, DTNB), S-acetylthiocholine iodide (ATCI), S-butyrylthiocholine iodide, and donepezil hydrochloride were purchased from Sigma Aldrich.

The experimental procedure described below for AChE was also applied to the BChE by replacing the S-acetylthiocholine by the S-butyrylthiocholine.

AChE solution was prepared in Tris $\cdot \mathrm{HCl}$ buffer $(\mathrm{pH}=8 ; 50 \mathrm{mM}$, with BSA (Bovine serum albumine) $0.1 \% \mathrm{w}$ ), and then diluted at an activity of $0.27 \mathrm{U}$ for non-symmetrical hybrids (the dilution was $0.5 \mathrm{U}$ for the symmetrical bis-pyridinium salts and bis-indolizines 1'-4' series, see Table S5). S-Acetylthiocholine iodide solution was prepared in ultrapure water, at the concentration of $15 \mathrm{mM}$. DTNB (5,5'-dithiobis(2-nitrobenzoic acid)) was diluted in phosphate buffer $(\mathrm{pH}=7.4 ; 1.5 \mathrm{mM})$.

The test solutions were prepared at a concentration of $20 \mathrm{mM}$ (stock solutions in DMSO) and then diluted with Tris $\cdot \mathrm{HCl}$ buffer $\left(\mathrm{pH}=8.0,50 \mathrm{mM}, 0.1 \mathrm{M} \mathrm{NaCl}, 0.02 \mathrm{M} \mathrm{MgCl}_{2}\right)$, freshly prepared solutions were used for assays performed in the same day.

In 96-well plates, $160 \mu \mathrm{L}$ of $1.5 \mathrm{mM}$ DTNB solution and $50 \mu \mathrm{L}$ of $\mathrm{AChE}(0.5$ or $0.27 \mathrm{U} / \mathrm{mL})$ solutions were incubated with $10 \mu \mathrm{L}$ of various concentrations of the tested compounds (final concentrations in wells were 100 to $0.04 \mu \mathrm{M}$ (compared to 20 to $0.05 \mu \mathrm{M}$ for the symmetrical compounds, Table S5) at $37{ }^{\circ} \mathrm{C}$, and then $30 \mu \mathrm{L}$ of acetylthiocholine iodide $(15 \mathrm{mM})$ were added. The absorbance was measured at 48s intervals for minimum 20 cycles at $405 \mathrm{~nm}$ wavelength with the Omega fluorescence plate reader (BMG LABTECH GmbH, Offenburg, Germany). IC50 values were obtained by plotting the initial velocities versus the concentrations of the tested compounds and using nonlinear regression analysis of the dose-response inhibition ([inhibitor] $v s$ response, 3 parameters) curve. Results were expressed as the mean \pm SD of at least three different experiments performed in triplicate. The blank does not contain any enzyme solution, its volume being replaced by ultrapure water. ${ }^{14}$

\section{Molecular docking calculations}

All modelling calculations were performed with the Schrödinger Suite version 2017-4.

Protein preparation: the crystal structures of the complexes of hAChE with

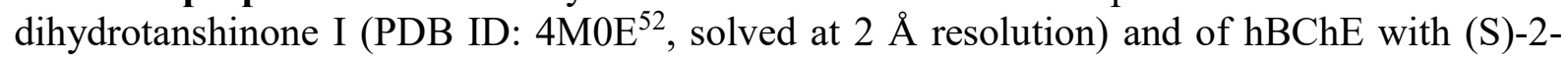


(butylamino)-N-(2-cycloheptylethyl)-3-(1H-indol-3-yl) propanamide (PDB ID:6QAA, solved at $1.9 \AA)^{53}$, were used for the docking calculations. The proteins were prepared using the Protein Preparation Wizard tool ${ }^{54}$. Missing side-chains were built and water molecules were retrieved. The partial atomic charges were derived from the OPLS3 force field ${ }^{55}$. Hydrogen atoms were added considering a $\mathrm{pH}$ of 7 and using the algorithm PropKa ${ }^{56}$. The orientation of the asparagine and glutamine side-chains were performed so as to maximize the hydrogen bond network. An all-atom energy minimization with a $0.3 \AA$ heavy-atom RMSD criteria for termination was performed using the Impref utility ${ }^{57}$ and OPLS3.

Ligand preparation. The low-energy conformers of the compounds were generated using the LigPrep module ${ }^{58}$. The ligands were docked flexibly; the parameters for van der Waals radii were scaled by 0.80 for atoms with partial charges less than $0.15 \mathrm{e}$, and non-planar amide bonds were penalized.

Relevant ionization and tautomeric states at $\mathrm{pH}$ comprised between 5 and 9 were generated using the Hammett and Taft methodology implemented in Epik ${ }^{59}$. The resulting conformations were energy-minimized using OPLS3 force field ${ }^{55}$ and a maximum of 100 conformations per ligand were generated and subjected to post-docking minimization.

Docking calculations. The Glide algorithm version $7.7^{60,61}$ in Standard precision mode with the OPLS3 force field was used. The receptors were considered as rigid, but the hydroxyls of Ser, Thr and Tyr residues were allowed to rotate, including residue Y337, known to adopt different conformers depending on the ligand that is co-crystallized ${ }^{62}$. A large receptor grid encompassing both the catalytic site and the peripheral site was generated for both enzymes. We used a scaling of van der Waals radii of 1 for atoms with partial charges less than $0.25 \mathrm{e}$. The shape and physico-chemical properties of the binding sites were mapped onto grids defined with large dimensions to reflect the presence of the two main binding sites. The dimensions of the receptor grids were respectively $36 * 42 * 35 \AA^{3}$ and $31 * 35 * 30 \AA^{3}$ for respectively the hAChE and $\mathrm{hBuChE}$ enzymes, centered on the co-crystallized ligand. Our docking procedure was validated as it was able to recover the binding pose of dihydrotanshinone $\mathrm{I}$ in hAChE with a RMSD of $0.017 \AA$.

\section{Study on amyloid fibers}

The AcPHF6 (Ac-VQIVYK-NH2) peptide was prepared as previously described ${ }^{31}$. The AcR3 peptide corresponds to G271-G323 $\Delta$ R2 tau fragment and was synthesized by Fmoc/tBu strategy on Rink amide MBHA resin.

Thioflavin T fluorescence assays. A typical ThT assay's microplate includes ThT control wells, peptide (AcPHF6 or R3) control wells and Ind-PyCx control wells. The wells were prepared in hexaplicate. The total volume of each well was $100 \mu \mathrm{L}$ for a final concentration of $100 \mu \mathrm{M}$ peptide, $10 \mu \mathrm{M}$ ThT, $10 \mu \mathrm{M}$ heparin (for AcR3) and $100 \mu \mathrm{M}$ Ind-PyCx with a maximum of $0.5 \%$ DMSO in $50 \mathrm{mM}$ phosphate buffer $\mathrm{pH} 7.4$. The assays were conducted in standard 96-well plates (U-shape, black, polypropylene, Greiner Bio-One, USA) in a POLARstar Omega fluorescence plate reader (BMG LABTECH GmbH, Offenburg, Germany) at room temperature (AcPHF6 peptide) or $37^{\circ} \mathrm{C}$ (AcR3 peptide) with excitation and emission wavelengths at $440 \mathrm{~nm}$ and $480 \mathrm{~nm}$, respectively. Fluorescence data were recorded every minute over $2 \mathrm{~h}$ (AcPHF6 peptide) or over $34 \mathrm{~h}$ (AcR3 peptides) with $10 \mathrm{~s}$ shaking (700 rpm) prior to each reading (top optic, orbital averaging of $3 \mathrm{~mm}$ diameter) with a gain of 1200 . Inhibitions reported in Figure 6 are calculated from the average of the hexaplicate, and the errors represent the SEM of three independent experiments performed in hexaplicates.

Absorption spectra. Absorption spectra were acquired on a spectrophotometer UV-1650 PC Shimadzu using an optical length of $10 \mathrm{~mm}$. Acquisitions were recorded from $200 \mathrm{~nm}$ to 600 
$\mathrm{nm}$. Samples were prepared to give a final concentration of $100 \mu \mathrm{M}$ Ind-PyCx with a maximum of $0.5 \%$ DMSO in $50 \mathrm{mM}$ phosphate buffer $\mathrm{pH} 7.4$.

Emission spectra. Emission spectra were acquired on a FluoroMax4 Horiba Spectrometer a quartz cell with a $3 \mathrm{~mm}$ path length and a maximum volume of $300 \mu \mathrm{L}$.

Emission spectra of Ind-PyCx series alone. They were recorded from $100 \mu \mathrm{M}$ Ind-PyCx alone in $50 \mathrm{mM}$ phosphate buffer $\mathrm{pH} 7.4$ with a maximum of $0.5 \%$ DMSO. Emission spectra of Ind$\boldsymbol{P y} \boldsymbol{C x}$ series in presence of pre-formed fibers. They were recorded after adding the Ind-PyCx solution in $50 \mathrm{mM}$ phosphate buffer $\mathrm{pH} 7.4$ (0.5\% DMSO) to preformed AcPHF6 fibers (or AcR3 fibers) in presence or without ThT. The final concentration of Ind-PyCx compounds in cell was $100 \mu \mathrm{M}$. AcPHF6 pre-formed fibers were prepared in an Eppendorf $\circledast$ Protein LoBind tube by incubating $100 \mu \mathrm{M}$ AcPHF6 peptide in phosphate buffer for $24 \mathrm{~h}$ at room temperature in absence or in presence of $10 \mu \mathrm{M}$ ThT (for the displacement assay). For AcR3 pre-formed fibers, they were prepared in an Eppendorf ${ }^{\circledR}$ Protein LoBind tube by incubating $100 \mu \mathrm{M}$ AcR3 peptide and $10 \mu \mathrm{M}$ heparin in phosphate buffer for $24 \mathrm{~h}$ at $37^{\circ} \mathrm{C}$ in absence or presence of 10 $\mu \mathrm{M}$ ThT (for the displacement assay).

Circular Dichroism. CD spectra were acquired on a JASCO J-810 spectropolarimeter (Jasco Corporation, Tokyo, Japan) using a quartz cell with a $1 \mathrm{~mm}$ path length and a maximum volume of $300 \mu \mathrm{L}$. Acquisitions were recorded at room temperature between $260 \mathrm{~nm}$ and $206 \mathrm{~nm}$ with a spectral resolution of $1 \mathrm{~nm}$, an average time of $1 \mathrm{~s}$ per data point and a band width of $10 \mathrm{~nm}$. The spectra reported represent an average of four acquisitions and have not be smoothed. The total volume of each quartz cell was $300 \mu \mathrm{L}$ for a final concentration of $100 \mu \mathrm{M}$ AcR3, $10 \mu \mathrm{M}$ heparin and $100 \mu \mathrm{M}$ Ind-PyCx in $50 \mathrm{mM}$ phosphate buffer $\mathrm{pH} 7.4$ with a maximum of $0.5 \%$ DMSO. Prior to the acquisitions in the quartz cell, the mixtures were incubated at $37^{\circ} \mathrm{C}$ for 24 $h$ in an Eppendorf ${ }^{\circledR}$ Protein LoBind tube.

Acknowledgments. This work has been partially supported by Labex Arcane, CBH-EURGS (ANR-17-EURE-0003), by the PolyNatCarnot Institute (Investissements d'Avenir -grant agreement $\left.n^{\circ} A N R-11-C A R N-007-01\right)$, by NeuroCoG IDEX UGA in the framework of the "Investissements d'avenir" program (ANR-15-IDEX-02) and), and by a grant of the Romanian National Authority for Scientific Reasearch and Innovation (CNCS-UEFISCDI, PN-II-IDPCE-2011-3-0226, CCCDI-UEFISCDI, project number 85BM/2017). The NanoBio ICMG (UAR 2607), is acknowledged for providing facilities for mass spectrometry analyses (A. Durand, L. Fort, R. Gueret) and for NMR analyses (M.-C. Molina).

\section{References and notes}

1. Small, S.; Mayeux, R., Alzheimer's disease and related dementias. Merrit's Neurology 2005, 107, 771-6.

2. Cummings, J.; Lee, G.; Ritter, A.; Sabbagh, M.; Zhong, K., Alzheimer's disease drug development pipeline: 2019. Alzheimer's Dement. 2019, 5, 272-293.

3. Anand, P.; Singh, B., A review on cholinesterase inhibitors for Alzheimer's disease. Arch. Pharm. Res. 2013, 36 (4), 375-399. 
4. de Freitas Silva, M.; Dias, K. S.; Gontijo, V. S.; Ortiz, C. J. C.; Viegas, J., Multi-target directed drugs as a modern approach for drug design towards Alzheimer's disease: an update. Curr. Med. Chem. 2018, 25 (29), 3491-3525.

5. Leon, R.; Garcia, A. G.; Marco-Contelles, J., Recent advances in the multitargetdirected ligands approach for the treatment of Alzheimer's disease. Med. Res. Rev. 2013, 33 (1), 139-189.

6. Mishra, P.; Kumar, A.; Panda, G., Anti-cholinesterase hybrids as multi-target-directed ligands against Alzheimer's disease (1998-2018). Bioorg. Med. Chem. 2019, 27 (6), 895-930.

7. Montanari, S.; Bartolini, M.; Neviani, P.; Belluti, F.; Gobbi, S.; Pruccoli, L.; Tarozzi, A.; Falchi, F.; Andrisano, V.; Miszta, P.; Cavalli, A.; Filipek, S.; Bisi, A.; Rampa, A., Multitarget Strategy to Address Alzheimer's Disease: Design, Synthesis, Biological Evaluation, and Computational Studies of Coumarin-Based Derivatives. ChemMedChem 2016, 11 (12), 1296-1308.

8. Ortiz, C. J. C.; de Freitas Silva, M.; Gontijo, V. S.; Viegas, F. P. D.; Dias, K. S. T.; Viegas, C., Design of Multi-target Directed Ligands as a Modern Approach for the Development of Innovative Drug Candidates for Alzheimer's Disease. In Methods in Pharmacology and Toxicology, Springer Science: New-York, 2018; pp 255-351.

9. Wang, T.; Liu, X.-h.; Guan, J.; Ge, S.; Wu, M.-B.; Lin, J.-p.; Yang, L.-r., Advancement of multi-target drug discoveries and promising applications in the field of Alzheimer's disease. Eur. J. Med. Chem. 2019, 169, 200-223.

10. Zhang, P.; Xu, S.; Zhu, Z.; Xu, J., Multi-target design strategies for the improved treatment of Alzheimer's disease. Eur. J. Med. Chem. 2019, 176, 228-247.

11. Singh, M.; Kaur, M.; Chadha, N.; Silakari, O., Hybrids: a new paradigm to treat Alzheimer's disease. Mol. Divers. 2016, 20 (1), 271-297.

12. Alipour, M.; Khoobi, M.; Foroumadi, A.; Nadri, H.; Moradi, A.; Sakhteman, A.; Ghandi, M.; Shafiee, A., Novel coumarin derivatives bearing N-benzyl pyridinium moiety: potent and dual binding site acetylcholinesterase inhibitors. Bioorg. Med. Chem. 2012, 20 (24), 7214-7222.

13. Baharloo, F.; Moslemin, M. H.; Nadri, H.; Asadipour, A.; Mahdavi, M.; Emami, S.; Firoozpour, L.; Mohebat, R.; Shafiee, A.; Foroumadi, A., Benzofuran-derived benzylpyridinium bromides as potent acetylcholinesterase inhibitors. Eur. J. Med. Chem. 2015, 93, 196-201.

14. Lan, J.-S.; Zhang, T.; Liu, Y.; Yang, J.; Xie, S.-S.; Liu, J.; Miao, Z.-Y.; Ding, Y., Design, synthesis and biological activity of novel donepezil derivatives bearing N-benzyl pyridinium moiety as potent and dual binding site acetylcholinesterase inhibitors. Eur. J. Med. Chem. 2017, 133, 184-196.

15. Palin, R.; Clark, J. K.; Cowley, P.; Muir, A. W.; Pow, E.; Prosser, A. B.; Taylor, R.; Zhang, M.-Q., Novel piperidinium and pyridinium agents as water-soluble acetylcholinesterase inhibitors for the reversal of neuromuscular blockade. Bioorg. Med. Chem. Lett. 2002, 12 (18), 2569-2572.

16. Vafadarnejad, F.; Karimpour-Razkenari, E.; Sameem, B.; Saeedi, M.; Firuzi, O.; Edraki, N.; Mahdavi, M.; Akbarzadeh, T., Novel N-benzylpyridinium moiety linked to arylisoxazole derivatives as selective butyrylcholinesterase inhibitors: Synthesis, biological evaluation, and docking study. Bioorg. Chem. 2019, 92, 103192.

17. Sowmiah, S.; Esperança, J. M.; Rebelo, L. P.; Afonso, C. A., Pyridinium salts: from synthesis to reactivity and applications. Org. Chem. Front. 2018, 5 (3), 453-493.

18. Sharma, P.; Srivastava, P.; Seth, A.; Tripathi, P. N.; Banerjee, A. G.; Shrivastava, S. K., Comprehensive review of mechanisms of pathogenesis involved in Alzheimer's disease and potential therapeutic strategies. Prog. Neurobiol. 2019, 174, 53-89. 
19. Ghinea, I. O.; Dinica, R. M., Breakthroughs in Indole and Indolizine Chemistry-New Synthetic Pathways, New Applications. In Scope of Selective Heterocycles from Organic and Pharmaceutical Perspective, IntechOpen: eBook, 2016.

20. Arvin-Berod, M.; Desroches-Castan, A.; Bonte, S.; Brugière, S.; Coute, Y.; Guyon, L.; Feige, J.-J.; Baussanne, I.; Demeunynck, M., Indolizine-based scaffolds as efficient and versatile tools: Application to the synthesis of biotin-tagged antiangiogenic drugs. ACS omega 2017, 2 (12), 9221-9230.

21. Choi, S.-K.; Rho, J.; Yoon, S. E.; Seok, J.-H.; Kim, H.; Min, J.; Yoon, W.; Lee, S.; Yun, H.; Kwon, O.-P., Full Color Tunable Aggregation-Induced Emission Luminogen for Bioimaging Based on an Indolizine Molecular Framework. Bioconjug. Chem. 2020, 31 (11), 2522-2532.

22. Kim, D.; Lee, J. H.; Kim, H. Y.; Shin, J.; Kim, K.; Lee, S.; Park, J.; Kim, J.; Kim, Y., Fluorescent indolizine derivative YI-13 detects amyloid- $\beta$ monomers, dimers, and plaques in the brain of 5XFAD Alzheimer transgenic mouse model. PloS one 2020, 15 (12), e0243041. 23. Singh, M.; Kaur, M.; Kukreja, H.; Chugh, R.; Silakari, O.; Singh, D., Acetylcholinesterase inhibitors as Alzheimer therapy: from nerve toxins to neuroprotection. Eur. J. Med. Chem. 2013, 70, 165-188.

24. Østby, O. B.; Dalhus, B.; Gundersen, L. L.; Rise, F.; Bast, A.; Haenen, G. R., Synthesis of 1-Substituted 7-Cyano-2, 3-diphenylindolizines and Evaluation of Antioxidant Properties. Eur. J. Org. Chem. 2000, 2000 (22), 3763-3770.

25. Gundersen, L.-L.; Malterud, K. E.; Negussie, A. H.; Rise, F.; Teklu, S.; Østby, O. B., Indolizines as novel potent inhibitors of 15-lipoxygenase. Bioorg. Med. Chem. 2003, 11 (24), 5409-5415.

26. Ahmed, M.; Rocha, J. B. T.; Mazzanti, C. M.; Morsch, A. L.; Cargnelutti, D.; Corrêa, M.; Loro, V.; Morsch, V. M.; Schetinger, M. R., Malathion, carbofuran and paraquat inhibit Bungarus sindanus (krait) venom acetylcholinesterase and human serum butyrylcholinesterase in vitro. Ecotoxicol. 2007, 16 (4), 363.

27. Kapková, P.; Alptüzün, V.; Frey, P.; Erciyas, E.; Holzgrabe, U., Search for dual function inhibitors for Alzheimer's disease: Synthesis and biological activity of acetylcholinesterase inhibitors of pyridinium-type and their $\mathrm{A} \beta$ fibril formation inhibition capacity. Bioorg. Med. Chem. 2006, 14 (2), 472-478.

28. Seto, Y.; Shinohara, T., Structure-activity relationship of reversible cholinesterase inhibitors including paraquat. Arch. Toxicol. 1988, 62 (1), 37-40.

29. Furdui, B.; Dinica, R.; Druta, I. I.; Demeunynck, M., Improved synthesis of cationic pyridinium-substituted indolizines. Synthesis 2006, 2006 (16), 2640-2642.

30. Rotaru, A.; Druta, I.; Avram, E.; Danac, R., Synthesis and properties of fluorescent 1, 3-substituted mono and biindolizines. Arkivoc 2009, 13, 287-299.

31. Lunven, L.; Bonnet, H.; Yahiaoui, S.; Yi, W.; Da Costa, L. n.; Peuchmaur, M.; Boumendjel, A.; Chierici, S., Disruption of fibers from the tau model AcPHF6 by naturally occurring aurones and synthetic analogues. ACS Chem. Neurosci. 2016, 7 (7), 995-1003.

32. Mohamed, T.; Hoang, T.; Jelokhani-Niaraki, M.; Rao, P. P., Tau-derived-hexapeptide 306VQIVYK311 aggregation inhibitors: nitrocatechol moiety as a pharmacophore in drug design. ACS Chem. Neurosci. 2013, 4 (12), 1559-1570.

33. Zheng, J.; Liu, C.; Sawaya, M. R.; Vadla, B.; Khan, S.; Woods, R. J.; Eisenberg, D.; Goux, W. J.; Nowick, J. S., Macrocyclic $\beta$-sheet peptides that inhibit the aggregation of a tauprotein-derived hexapeptide. J. Am. Chem. Soc. 2011, 133 (9), 3144-3157.

34. Goux, W. J.; Kopplin, L.; Nguyen, A. D.; Leak, K.; Rutkofsky, M.; Shanmuganandam, V. D.; Sharma, D.; Inouye, H.; Kirschner, D. A., The formation of straight and twisted filaments from short tau peptides. J. Biol. Chem. 2004, 279 (26), 26868-26875. 
35. Kalász, H.; Nurulain, S.; Veress, G.; Antus, S.; Darvas, F.; Adeghate, E.; Adem, A.; Hashemi, F.; Tekes, K., Mini review on blood-brain barrier penetration of pyridinium aldoximes. J. Appl. Toxicol. 2015, 35 (2), 116-123.

36. Tsuji, A., Small molecular drug transfer across the blood-brain barrier via carriermediated transport systems. NeuroRx 2005, 2 (1), 54-62.

37. Wager, T. T.; Chandrasekaran, R. Y.; Hou, X.; Troutman, M. D.; Verhoest, P. R.; Villalobos, A.; Will, Y., Defining desirable central nervous system drug space through the alignment of molecular properties, in vitro ADME, and safety attributes. ACS Chem. Neurosci. 2010, 1 (6), 420-434.

38. Pajouhesh, H.; Lenz, G. R., Medicinal chemical properties of successful central nervous system drugs. NeuroRx 2005, 2 (4), 541-553.

39. The bis-pyridinium di-cations 17-20 (and their symmetrical analogs 1'a-c and 2'a-c, Table S1) are too polar (strongly negative $\operatorname{LogP}$ ). It is also interesting to notice that the bisindolizines (7,7'-bis-indolizines 3'a-c and bis(indolizin-7-yl)ethane 4'a-c) do not in general follow the rules as they are too lipophilic ( $\log P>6)$, showing both higher MW and PSA values (see Table S1). Their calculated high lipophilicity is experimentally correlated to a low solubility in water with formation of aggregates

40. Klopman, G.; Li, J.-Y.; Wang, S.; Dimayuga, M., Computer Automated $\log$ P Calculations Based on an Extended Group Contribution Approach. J. Chem. Inf. Comput. Sci. 1994, 34 (4), 752-781.

41. Ellman, G. L.; Courtney, K. D.; Andres, V.; Featherstone, R. M., A new and rapid colorimetric determination of acetylcholinesterase activity. Biochem. Pharmacol. 1961, 7 (2), 88-95.

42. Shen, Q.; Zhang, B.; Xu, R.; Wang, Y.; Ding, X.; Li, P., Antioxidant activity in vitro of the selenium-contained protein from the Se-enriched Bifidobacterium animalis 01. Anaerobe 2010, 16 (4), 380-386.

43. Levine III, H., Thioflavine T interaction with synthetic Alzheimer's disease $\beta$-amyloid peptides: Detection of amyloid aggregation in solution. Protein Sci. 1993, 2 (3), 404-410.

44. Gade Malmos, K.; Blancas-Mejia, L. M.; Weber, B.; Buchner, J.; Ramirez-Alvarado, M.; Naiki, H.; Otzen, D., ThT 101: a primer on the use of thioflavin T to investigate amyloid formation. Amyloid 2017, 24 (1), 1-16.

45. Jameson, L. P.; Smith, N. W.; Dzyuba, S. V., Dye-binding assays for evaluation of the effects of small molecule inhibitors on amyloid (A $\beta)$ self-assembly. ACS Chem. Neurosci. 2012, 3 (11), 807-819.

46. Hudson, S. A.; Ecroyd, H.; Kee, T. W.; Carver, J. A., The thioflavin T fluorescence assay for amyloid fibril detection can be biased by the presence of exogenous compounds. FEBS J. 2009, 276 (20), 5960-5972.

47. Yang, J.; Guo, J.; Yuan, J., In vitro antioxidant properties of rutin. Food Sci. Technol. 2008, 41 (6), 1060-1066.

48. For comparison the evaluation of the symmetrical analogs was made (see Table S1) using eeAChE at a concentration of $0.5 \mathrm{U}$. Compounds 1'a-b, 2'a, 2'c, 3'a-b exhibited micromolar IC50 values $(2-5 \mu \mathrm{M})$

49. Liederer, B. M.; Borchardt, R. T., Enzymes involved in the bioconversion of ester-based prodrugs. J. Pharm. Sci. 2006, 95 (6), 1177-1195.

50. Furdui, B.; Constantin, O.; Tabacaru, A.; Dinica, R., New bis-pyridinium diquaternary salts with antimicrobial properties. Rev. Chim 2012, 63, 667-671.

51. Taffa, D. H.; Kathiresan, M.; Walder, L.; Seelandt, B.; Wark, M., Pore size and surface charge control in mesoporous TiO 2 using post-grafted SAMs. Phys. Chem. Chem. Phys. 2010, $12(7), 1473-1482$. 
52. Cheung, J.; Gary, E. N.; Shiomi, K.; Rosenberry, T. L., Structures of human acetylcholinesterase bound to dihydrotanshinone I and territrem B show peripheral site flexibility. ACS Med. Chem. Lett. 2013, 4 (11), 1091-1096.

53. Meden, A.; Knez, D.; Jukič, M.; Brazzolotto, X.; Gršič, M.; Pišlar, A.; Zahirović, A.; Kos, J.; Nachon, F.; Svete, J., Tryptophan-derived butyrylcholinesterase inhibitors as promising leads against Alzheimer's disease. Chem. Commun. 2019, 55 (26), 3765-3768.

54. Sastry, G. M.; Adzhigirey, M.; Day, T.; Annabhimoju, R.; Sherman, W., Protein and ligand preparation: parameters, protocols, and influence on virtual screening enrichments. $J$. Comput. Aided Mol. Des. 2013, 27 (3), 221-234.

55. Harder, E.; Damm, W.; Maple, J.; Wu, C.; Reboul, M.; Xiang, J. Y.; Wang, L.; Lupyan, D.; Dahlgren, M. K.; Knight, J. L., OPLS3: a force field providing broad coverage of drug-like small molecules and proteins. J. Chem. Theory Comput. 2016, 12 (1), 281-296.

56. Li, H.; Robertson, A. D.; Jensen, J. H., Very fast empirical prediction and rationalization of protein pKa values. Proteins 2005, 61 (4), 704-721.

57. Banks, J. L.; Beard, H. S.; Cao, Y.; Cho, A. E.; Damm, W.; Farid, R.; Felts, A. K.; Halgren, T. A.; Mainz, D. T.; Maple, J. R., Integrated modeling program, applied chemical theory (IMPACT). J. Comput. Chem. 2005, 26 (16), 1752-1780.

58. LigPrep, LigPrep version 3.5 Schrödinger, LLC, New York, NY, 2015. 2015.

59. Epik, Epik version 4.2 Schrödinger, LLC, New York, NY, 2017. 2017.

60. Friesner, R. A.; Banks, J. L.; Murphy, R. B.; Halgren, T. A.; Klicic, J. J.; Mainz, D. T.; Repasky, M. P.; Knoll, E. H.; Shelley, M.; Perry, J. K., Glide: a new approach for rapid, accurate docking and scoring. 1. Method and assessment of docking accuracy. J. Med. Chem. 2004, 47 (7), 1739-1749.

61. Glide, Glide version 7.7, Schrödinger, LLC, New York, NY, 2017. 2017.

62. Hameed, A.; Zehra, S. T.; Shah, S. J.; Khan, K. M.; Alharthy, R. D.; Furtmann, N.; Bajorath, J.; Tahir, M. N.; Iqbal, J., Syntheses, cholinesterases inhibition, and molecular docking studies of Pyrido [2, 3-b] pyrazine derivatives. Chem. Biol. Drug Des. 2015, 86 (5), 1115-1120. 